University of Nebraska - Lincoln

DigitalCommons@University of Nebraska - Lincoln

\title{
Secondary mineralization pathways induced by dissimilatory iron reduction of ferrihydrite under advective flow
}

\author{
Colleen M. Hansel \\ Stanford University, hansel@stanford.edu \\ Shawn G. Benner \\ Stanford University \\ Jim Neiss \\ Stanford University \\ Alice Dohnalkova \\ Pacific Northwest National Laboratory \\ Ravi K. Kukkadapu \\ Pacific Northwest National Laboratory, ravi.kukkadapu@pnl.gov \\ See next page for additional authors
}

Follow this and additional works at: https://digitalcommons.unl.edu/usdoepub

Part of the Bioresource and Agricultural Engineering Commons

Hansel, Colleen M.; Benner, Shawn G.; Neiss, Jim; Dohnalkova, Alice; Kukkadapu, Ravi K.; and Fendorf, Scott, "Secondary mineralization pathways induced by dissimilatory iron reduction of ferrihydrite under advective flow" (2003). US Department of Energy Publications. 155.

https://digitalcommons.unl.edu/usdoepub/155

This Article is brought to you for free and open access by the U.S. Department of Energy at DigitalCommons@University of Nebraska - Lincoln. It has been accepted for inclusion in US Department of Energy Publications by an authorized administrator of DigitalCommons@University of Nebraska - Lincoln. 


\section{Authors}

Colleen M. Hansel, Shawn G. Benner, Jim Neiss, Alice Dohnalkova, Ravi K. Kukkadapu, and Scott Fendorf 


\title{
Secondary mineralization pathways induced by dissimilatory iron reduction of ferrihydrite under advective flow
}

\author{
Colleen M. Hansel, ${ }^{1, *}$ Shawn G. Benner, ${ }^{1, \dagger}$ Jim Neiss, ${ }^{1}$ Alice Dohnalkova, ${ }^{2}$ Ravi K. Kukkadapu, ${ }^{2}$ and Scott Fendorf ${ }^{1, *}$ \\ ${ }^{1}$ Department of Geological and Environmental Sciences, Braun Hall, Building 320, Room 118, Stanford University, Stanford, CA 94305 , USA \\ ${ }^{2}$ Pacific Northwest National Laboratory, Richland, WA 99352, USA
}

(Received October 1, 2002; revised 16 April 2003; accepted in revised form April 16, 2003)

\begin{abstract}
Iron (hydr)oxides not only serve as potent sorbents and repositories for nutrients and contaminants but also provide a terminal electron acceptor for microbial respiration. The microbial reduction of $\mathrm{Fe}$ (hydr)oxides and the subsequent secondary solid-phase transformations will, therefore, have a profound influence on the biogeochemical cycling of $\mathrm{Fe}$ as well as associated metals. Here we elucidate the pathways and mechanisms of secondary mineralization during dissimilatory iron reduction by a common iron-reducing bacterium, Shewanella putrefaciens (strain CN32), of 2-line ferrihydrite under advective flow conditions. Secondary mineralization of ferrihydrite occurs via a coupled, biotic-abiotic pathway primarily resulting in the production of magnetite and goethite with minor amounts of green rust. Operating mineralization pathways are driven by competing abiotic reactions of bacterially generated ferrous iron with the ferrihydrite surface. Subsequent to the initial sorption of ferrous iron on ferrihydrite, goethite (via dissolution/reprecipitation) and/or magnetite (via solid-state conversion) precipitation ensues resulting in the spatial coupling of both goethite and magnetite with the ferrihydrite surface. The distribution of goethite and magnetite within the column is dictated, in large part, by flow-induced ferrous Fe profiles. While goethite precipitation occurs over a large $\mathrm{Fe}$ (II) concentration range, magnetite accumulation is only observed at concentrations exceeding 0.3 $\mathrm{mmol} / \mathrm{L}$ (equivalent to $0.5 \mathrm{mmol} \mathrm{Fe}[\mathrm{II}] / \mathrm{g}$ ferrihydrite) following $16 \mathrm{~d}$ of reaction. Consequently, transportregulated ferrous $\mathrm{Fe}$ profiles result in a progression of magnetite levels downgradient within the column. Declining microbial reduction over time results in lower Fe(II) concentrations and a subsequent shift in magnetite precipitation mechanisms from nucleation to crystal growth. While the initial precipitation rate of goethite exceeds that of magnetite, continued growth is inhibited by magnetite formation, potentially a result of lower Fe(III) activity. Conversely, the presence of lower initial Fe(II) concentrations followed by higher concentrations promotes goethite accumulation and inhibits magnetite precipitation even when Fe(II) concentrations later increase, thus revealing the importance of both the rate of Fe(II) generation and flow-induced $\mathrm{Fe}$ (II) profiles. As such, the operating secondary mineralization pathways following reductive dissolution of ferrihydrite at a given $\mathrm{pH}$ are governed principally by flow-regulated $\mathrm{Fe}(\mathrm{II})$ concentration, which drives mineral precipitation kinetics and selection of competing mineral pathways. Copyright (C) 2003 Elsevier Ltd
\end{abstract}

\section{INTRODUCTION}

The importance of microorganisms in the biogeochemical cycling of Fe is well-recognized (Lovley, 1991; Nealson and Saffarini, 1994). Dissimilatory iron-reducing bacteria (DIRB), which are ubiquitous in soils and aquifers, couple the oxidation of organic matter or $\mathrm{H}_{2}$ with the reduction of various $\mathrm{Fe}(\mathrm{III})$ oxide phases to obtain energy for growth and function. While $\mathrm{H}_{2} \mathrm{~S}$ may be an appreciable reductant of iron oxides in sulfidogenic environments (dos Santos Afonso and Stumm, 1992), DIRB catalyze most of the $\mathrm{Fe}(\mathrm{III})$ reduction occurring under non-sulfidogenic, anaerobic conditions (Lovley et al., 1991). Although iron-reducing bacteria can utilize crystalline iron oxides as well as poorly crystalline phases, the latter are considered the primary terminal electron acceptor for DIRB (Kostka and Nealson, 1995; Roden and Zachara, 1996; Roden et al., 2000; Zachara et al., 2001, 2002). This phenomenon is thought to be responsible for the persistence of more crystalline

\footnotetext{
* Authors to whom correspondence should be addressed (hansel@ stanford.edu) (fendorf@stanford.edu).

${ }^{\dagger}$ Present address: Division of Hydrologic Sciences, Desert Research Institute, Las Vegas, NV 89119, USA.
}

iron oxides in the environment (Lovley and Phillips, 1986; Phillips et al., 1993; Schwertmann and Cornell, 2000).

Ferrous iron containing solid-phases observed in batch (closed) systems following microbial respiration of ferrihydrite under varying environmental conditions include siderite $\left(\mathrm{FeCO}_{3}\right)$, magnetite $\left(\mathrm{Fe}^{\mathrm{II}} \mathrm{Fe}^{\mathrm{III}}{ }_{2} \mathrm{O}_{4}\right)$, vivianite $\left(\mathrm{Fe}_{3}\left[\mathrm{PO}_{4}\right]_{2}\right.$. $\left.\mathrm{nH}_{2} \mathrm{O}\right)$, and green rust $\left(\left[\mathrm{Fe}^{\mathrm{III}}{ }_{(6-\mathrm{x})} \mathrm{Fe}^{\mathrm{IIII}}{ }_{\mathrm{x}}(\mathrm{OH})_{12}\right]^{\mathrm{x}+}\left[\left(\mathrm{A}^{2-}\right)_{\mathrm{x} / 2}\right.\right.$. $\mathrm{yH}_{2} \mathrm{O}^{\mathrm{x}-}{ }^{-}$) (Lovley et al., 1987; Lovley and Phillips, 1988; Roden and Lovley, 1993; Mortimer and Coleman, 1997; Fredrickson et al., 1998; Cooper et al., 2000; Zachara et al., 2002). The chemical environment in which microbial iron reduction occurs determines the rate and extent of iron reduction and the nature of the reduced solids (Fredrickson et al., 1998; Zachara et al., 2002). Factors dictating the specific biomineralization pathway may include $\mathrm{pH}$, redox potential, carbonate concentration and, mostly, respiration-driven Fe(II) supply rate and magnitude (Fredrickson et al., 1998; Zachara et al., 2002).

Microbial reduction of crystalline and poorly crystalline iron oxides can be limited in static systems through passivation of the oxide and cell surface by $\mathrm{Fe}(\mathrm{II})$ (adsorbed species and secondary precipitates) (Roden and Zachara, 1996). Introduction of advective flow, however, allows for near complete reductive dissolution of crystalline iron oxides (goethite) by 
DIRB (Roden and Urrutia, 1999; Roden et al., 2000). We previously investigated prolonged $(50 \mathrm{~d})$ microbial reduction of short-range ordered $\mathrm{Fe}(\mathrm{III})$ oxides by Shewanella putrefaciens (strain CN32) under advective flow in an artificial groundwater and bicarbonate buffered media (Benner et al., 2002). Even after $50 \mathrm{~d}$ of reaction, $\sim 70 \%$ of the original $\mathrm{Fe}(\mathrm{III})$ remained, with goethite and magnetite being the predominant solid-phase products. The concentration of magnetite increased downgradient, thus lending support to the proposed hypothesis that secondary mineralization was controlled principally by Fe(II) concentration; low concentrations induced ferrihydrite ripening, whereas higher $\mathrm{Fe}(\mathrm{II})$ concentrations promoted secondary mineralization of ferrous- or ferric-ferrous-bearing minerals (Zachara et al., 2002). However, the factors dictating the operating mineralization pathways following ferrihydrite reductive dissolution remained unclear. Accordingly, the mechanisms of $\mathrm{Fe}$ biomineralization following dissimilatory reduction of 2-line ferrihydrite under advective flow were investigated. The progression of $\mathrm{Fe}$ phase transformations was monitored both temporally and spatially (throughout the column) using a suite of spectroscopic and microscopic techniques. Here we reveal that the secondary mineralization of ferrihydrite occurs via a coupled, two-step biotic-abiotic pathway, whereby subsequent mineral assemblages are dictated by a complex interplay between microbial metabolism, aqueous chemistry, and kinetically regulated mineral precipitation.

\section{EXPERIMENTAL METHODS AND PROCEDURES}

\subsection{Preparation of Media and Bacterial Cultures}

We examined microbially induced Fe mineral transformations using S. putrefaciens strain CN32 in an artificial groundwater medium under advective flow. S. putrefaciens is a facultative, dissimilatory ironreducing bacterium (DIRB) that couples the incomplete oxidization of lactate to acetate with $\mathrm{Fe}$ (III) reduction. Standard methods for culture of anaerobic bacteria and preparation of anoxic media were used throughout. Media and buffers were made anoxic by boiling and cooling under a stream of $\mathrm{O}_{2}$-free $\mathrm{N}_{2}$ or $\mathrm{N}_{2}: \mathrm{CO}_{2}(80: 20)$ gas. All reactions were performed in an anaerobic chamber (Coy Laboratories, Inc., Grass Lake, MI) with a $\mathrm{N}_{2}(90 \%): \mathrm{H}_{2}(10 \%)$ atmosphere. S. putrefaciens was grown aerobically to late $\log$ phase in tryptic soy broth (TSB, DIFCO, Detroit, MI) at room temperature and frozen in $20 \%$ glycerol at $-80^{\circ} \mathrm{C}$. Seed cultures were started from frozen stocks $(1 \mathrm{~mL}$ in $100 \mathrm{~mL}$ TSB) and grown aerobically for $12 \mathrm{~h}$ at room temperature (150 rpm). Cell suspensions were prepared by adding $1 \mathrm{~mL}$ of the seed culture to $100 \mathrm{~mL}$ of TSB and grown to late $\log$ phase $\left(12 \mathrm{~h}, 25^{\circ} \mathrm{C}, 150\right.$ $\mathrm{rpm})$. Cells were harvested by centrifugation $\left(4500 \mathrm{~g}, 10 \mathrm{~min}, 5^{\circ} \mathrm{C}\right)$, washed twice in $100 \mathrm{~mL}$ of bicarbonate buffer $\left(2.5 \mathrm{~g} \mathrm{NaHCO}_{3} / \mathrm{L}\right.$ and $2.5 \mathrm{~g} \mathrm{NaCl} / \mathrm{L}, \mathrm{pH} 7.0$ ) and resuspended in an artificial groundwater medium. The artificial groundwater medium contained the following ingredients (in $\mathrm{mg} / \mathrm{L}$ ): $\mathrm{NaCl}, 30 ; \mathrm{NH}_{4} \mathrm{Cl}, 0.95 ; \mathrm{KCl}, 5 ; \mathrm{MgSO}_{4}, 50$; $\mathrm{KH}_{2} \mathrm{PO}_{4}, 0.95$; and $1 \mathrm{~mL}$ mineral solution (Balch et al., 1979). Lactate (as sodium lactate) was added as the electron donor to give a final concentration of $3 \mathrm{mmol} / \mathrm{L}$. The medium was equilibrated with calcite $(0.4 \mathrm{~g} / \mathrm{L})$ and $\mathrm{CO}_{2}$ at $0.02 \mathrm{~atm}(\mathrm{pH}=7)$. Batch studies indicate that the groundwater medium supports microbial growth.

Two-line ferrihydrite-coated quartz sand was prepared following the method of Brooks et al. (1996). The sand was coated with ferrihydrite by titrating a ferric chloride solution with $\mathrm{NaOH}$ to a $\mathrm{pH}$ of 7.5 . The titration was conducted rapidly $(<5 \mathrm{~min})$ to avoid precipitation of akaganeite. After washing the ferrihydrite floc with a dilute $\mathrm{NaCl}$ solution $(0.01 \mathrm{~mol} / \mathrm{L}, \mathrm{pH}$ adjusted to 7$)$, quartz sand was added to the suspension. Excess water was decanted and the remaining solution and sand allowed to evaporate at $20^{\circ} \mathrm{C}$ under convection while the mixture was periodically stirred. The coated sand was dried at $20^{\circ} \mathrm{C}$ for $4 \mathrm{~d}$ and then resaturated with water and heat sterilized. Both X-ray diffraction
(XRD) and X-ray absorption spectroscopy (XAS) verified that the precipitate was purely 2 -line ferrihydrite, which remained so for $>6$ months when precipitated on quartz sand and stored in DI water. No change in mineralogical composition (XAS and XRD) or surface area (BET analysis) was noted following sterilization of the 2-line ferrihydrite-coated sand. Freshly precipitated 2-line ferrihydrite-coated sand was inoculated with $S$. putrefaciens to a cell density of $\sim 10^{8} \mathrm{~mL}^{-1}$ before loading the columns.

\subsection{Column Design and Flow Conditions}

Experiments were conducted using three columns having a $3.8-\mathrm{cm}$ (inner) diameter and a $25-\mathrm{cm}$ length; solution sampling ports were located every $2.5 \mathrm{~cm}$ along the length of the column. Inoculated ferrihydrite-coated sand was added under continuous vibration to obtain uniform packing and allowed to equilibrate for $1 \mathrm{~h}$ before initiating flow. Flow velocities upward through the column were maintained at approximately three pore volumes per day, equivalent to a pore water velocity of $\sim 0.6 \mathrm{~m} \mathrm{~d}^{-1}$. Slower flow column experiments were conducted under identical conditions except with a flow velocity of $\sim 0.1$ $\mathrm{m} \mathrm{d}^{-1}$. All experiments were conducted in an anaerobic glove bag.

\subsection{Abiotic Batch Systems}

The role of bacteria in secondary mineralization was investigated by performing abiotic reactions with ferrihydrite. Reactions were performed in $250-\mathrm{mL}$ serum vials containing either ferrous chloride or ferrous sulfate and 2-line ferrihydrite-coated sand within anaerobic PIPES (1,4-piperazinediethanesulfonic acid) buffer. The role of Fe(II) concentration on secondary mineralization was investigated by reacting ferrous chloride over a range of 0 to $4.6 \mathrm{mmol} / \mathrm{L}$ with ferrihydrite for $9 \mathrm{~d}$. Vials were maintained anaerobic and gently shaken to minimize diffusion effects. Samples were extracted anaerobically using a sterile syringe and analyzed for $\mathrm{pH}$ and aqueous $\mathrm{Fe}$ (II) concentration. All reactions were performed in triplicate.

\subsection{Sampling and Analyses}

All three columns were connected to a communal pump and feed solution to minimize heterogeneity. The columns were terminated at 2 , 4 , and $16 \mathrm{~d}$ to obtain a time-series of solid-phase evolution. Upon termination, the solids were carefully extracted and homogenized at $2-\mathrm{cm}$ intervals along the length of the column. Solids from both the biotic and abiotic systems intended for X-ray absorption spectroscopic analyses were dried unaltered in the anaerobic glovebox, mounted on a Teflon plate, and sealed with Kapton polymide film to prevent moisture loss and oxidation while minimizing X-ray adsorption. Solids used for Mössbauer analyses were mildly sonicated $(\sim 10 \mathrm{~min})$ to remove the $\mathrm{Fe}$ from the quartz sand and dried in the glovebox. Solids remained in the glovebox until time of analysis. Reproducibility of the bacterial, solution, and solid-phase results were tested by duplicating the 4-d-reacted column; the columns were equivalent. Reproducibility of solution data was also tested by comparison among columns for overlapping time periods. Bacterial, solution, and solid-phase analyses were conducted as described in the following subsections.

\subsubsection{Bacteria}

Bacteria were enumerated and checked for purity at the conclusion of the column experiments using plate counts. A 1-g sample of ironcoated sand was added to $9 \mathrm{~mL}$ of $0.01 \mathrm{~mol} / \mathrm{L}$ sodium pyrophosphate and subjected to low-level sonication before serial dilution and plating on tryptic soy agar.

\subsubsection{Solution}

Solution from the feed, effluent, and side sampling ports were obtained for major dissolved constituents and $\mathrm{pH}$ as a function of time. Production of soluble $\mathrm{Fe}(\mathrm{II})$ was monitored spectrophotometrically at $562 \mathrm{~nm}$ using the ferrozine assay (Stookey, 1970). Total dissolved Fe and other major ions $(\mathrm{Ca}, \mathrm{K}, \mathrm{Mg}, \mathrm{P}, \mathrm{Si}, \mathrm{Na})$ were determined by inductively coupled plasma optical emission spectroscopy (ICP-OES). 
Acetate and lactate concentrations were obtained using ion chromatography (IC).

\subsubsection{Solid-Phase}

2.4.3.1. Extractions. Solid-phase extractions were performed by adding $1 \mathrm{~mL}$ of concentrated $(6 \mathrm{~mol} / \mathrm{L})$ hydrochloric acid to $1 \mathrm{~g}$ of sample and shaking for $8 \mathrm{~h}$. The supernatant was filtered, diluted with DI water and analyzed via ICP-OES for total Fe and with the ferrozine assay for $\mathrm{Fe}(\mathrm{II})$.

2.4.3.2. Spectroscopy. The speciation and structural environment of $\mathrm{Fe}$ were determined using X-ray absorption spectroscopy (XAS). XAS analyses were conducted on beamline 4-1 and 4-3 (8 pole wiggler) at the Stanford Synchrotron Radiation Laboratory (SSRL), running under dedicated conditions. The ring operated at $3 \mathrm{GeV}$ with a current ranging from $\sim 100$ to $50 \mathrm{~mA}$. Energy selection was accomplished using a Si (220) monochromator with an unfocused beam. Spectra were recorded by fluorescent $\mathrm{X}$-ray production using a wide-angle ionization chamber for all samples (Lytle et al., 1984). A 3- $\mu$ x Mn filter and Soller slits were used to minimize the effects of scattered primary radiation. Incident and transmitted intensities were measured with in-line ionization chambers. Higher-order harmonic frequencies were rejected by detuning 50 to $60 \%$ from the maximum incident intensity. Extended X-ray absorption fine structure (EXAFS) spectra were collected from -200 to $+1000 \mathrm{eV}$ about the K-edge of Fe. Each scan was calibrated internally by placing an iron metal foil between the second and third in-line ionization chambers and setting the first inflection point of $\mathrm{Fe}^{0}$ to $7111.0 \mathrm{eV}$. Between 7 and 10 individual spectra were averaged for each sample.

Fluorescence spectra were background subtracted and the atomic absorption was normalized to unity. Isolation of backscattering contributions was accomplished by fitting a spline function to the absorption envelope and then subtracting it from the spectra. The isolated function was then transformed from units of $\mathrm{eV}$ to $\AA^{-1}$ to produce the EXAFS function $(\chi[k])$, where $k\left(\AA^{-1}\right)$ is the photoelectron wave vector, which was then weighted by $k^{3}$. A set of reference standards for $\mathrm{Fe}$ was utilized to perform linear combination $k^{3}$-weighted EXAFS spectral fitting using the EXAFSPAK module DATFIT (George, 1993). Linear fitting routines were used to reconstruct the unknown to determine the relative percentages of mineral phases within the samples. Linear combinations of empirical model spectra were optimized where the only adjustable parameters were the fractions of each model compound contributing to the fit. Fits were optimized by minimizing the residual, defined as the normalized root square difference between the data and the fit. Accuracy of linear combination analysis was investigated by fitting a set of mixed standards having known fractions. Fits were within $\pm 5 \%$ of the actual mole percentages using the $k$-range 1 to 14 $\AA^{-1}$. The detection limit for minor constituents was $\sim 5 \%$.

Model Fe compounds used in linear combination fits include siderite $\left(\mathrm{FeCO}_{3}\right), 2-$ and 6-line ferrihydrite $\left[\mathrm{Fe}(\mathrm{OH})_{3} \cdot \mathrm{nH}_{2} \mathrm{O}\right]$, goethite $(\alpha-$ $\mathrm{FeOOH})$, lepidocrocite $(\gamma$-FeOOH$)$, hematite $\left(\alpha-\mathrm{Fe}_{2} \mathrm{O}_{3}\right)$, green rust $\left(\mathrm{Fe}_{6-\mathrm{x}}^{\mathrm{II}} \mathrm{Fe}^{\mathrm{III}}{ }_{x}[\mathrm{OH}]_{12}\left[\left(\mathrm{SO}_{4}\right)_{\mathrm{x} / 2} \cdot 3 \mathrm{H}_{2} \mathrm{O}\right]\right)$, iron sulfide $(\mathrm{FeS})$, vivianite $\left(\mathrm{Fe}_{3}\left[\mathrm{PO}_{4}\right]_{2} \cdot \mathrm{nH}_{2} \mathrm{O}\right)$, and magnetite $\left(\mathrm{Fe}_{3} \mathrm{O}_{4}\right)$. Siderite, vivianite, and magnetite were natural samples obtained from the Stanford University Mineral Collection. Goethite, ferrihydrite, and lepidocrocite were synthesized following the procedures of Schwertmann and Cornell (2000) and green rust following Schwertmann and Fechter (1994). Iron sulfide was produced by the method described in Morse and Arakaki (1993). Synthesized standards were verified using X-ray diffraction (XRD).

Qualitative and quantitative confirmation of the EXAFS results were obtained using Mössbauer spectroscopy and electron microscopy. Similar to EXAFS analysis, Mössbauer spectroscopy provides information on minerals that do not exhibit long-range structural order. It is also very sensitive to minor constituents (detection limit $\sim 1 \mathrm{wt} . \%$ ) but is compromised by nanometer-sized particles. Approximately 25 to 30 mg of dry sample were used to prepare a Mössbauer disk. Details of the sample preparation, instrumentation, data collection, calibration (20-mm a-Fe foil at RT), and folding of the data have been described previously (Fredrickson et al., 2001). For liquid nitrogen (77 K) measurements, both the source and drive assembly were at RT. All Mössbauer spectra were fit with quadrupole splitting (QSDs) and/or hyper-
Table 1. Solution composition used in geochemical modeling.

\begin{tabular}{lcc}
\hline & Day $1(\mathrm{mmol} / \mathrm{L})$ & Day $15(\mathrm{mmol} / \mathrm{L})$ \\
\hline $\mathrm{Ca}$ & 3.56 & 3.21 \\
$\mathrm{C} 1$ & 1.10 & 0.95 \\
$\mathrm{Fe}(\mathrm{II})$ & 0.97 & 0.21 \\
$\mathrm{~K}$ & 0.13 & 0.08 \\
$\mathrm{Mg}$ & 0.51 & 0.44 \\
$\mathrm{Na}$ & 0.53 & 0.24 \\
$\mathrm{P}$ as $\mathrm{PO}_{4}$ & 0.002 & 0.0002 \\
$\mathrm{~S}$ as $\mathrm{SO}_{4}$ & 0.05 & 0.45 \\
$\mathrm{Si}$ as $\mathrm{H}_{4} \mathrm{SiO}_{4}$ & 0.15 & 0.05 \\
$\mathrm{pH}$ & 7.16 & 7.29 \\
Eh & 39 & 59 \\
Alkalinity $(\mathrm{mg} / \mathrm{L} \mathrm{CaCO}$ & & 192 \\
\hline
\end{tabular}

$\mathrm{Fe}(\mathrm{III})$ concentrations estimated by equilibrium with measured $\mathrm{Eh}$ and $\mathrm{Fe}(\mathrm{II}) / \mathrm{Fe}(\mathrm{III})$ redox couple.

fine splitting distributions (HFDs) using the Voigt-based fitting method of Rancourt and Ping (1991).

2.4.3.3. Microscopy. Crystal size, morphology, and spatial relationships were identified using scanning electron (SEM) and transmission electron microscopies (TEM). Samples for SEM were dispersed onto carbon-coated $\mathrm{Cu}$ grids and allowed to dry in a glovebox. Samples were transported to the SEM in anaerobic containers and analyzed using a Philips XL30 FEG SEM fitted with backscatter and secondary electron detectors and an IMIX energy dispersive X-ray analytical system. Solid-phases were prepared for TEM by fixing the cells in $2.5 \%$ glutaraldehyde, rinsing three times in bicarbonate buffered media, dehydrating in an ethanol series, and embedding in LR white resin. The polymerized sections were anaerobically sectioned on a microtome. Samples were stored anaerobically and were only exposed to oxygen during the transfer $(<1 \mathrm{~min})$ to the high-vacuum sample chamber of the TEM. The samples were analyzed using a JEOL 2010 TEM operating at $200 \mathrm{kV}$.

2.4.4.4. Geochemical modeling. Saturation indices (SI) for a suite of potentially precipitating mineral phases were computed using solution data (Table 1) and the chemical speciation program MINTEQA2 (Allison et al., 1990). Saturation indices (Table 2) were calculated for effluent waters during the initial period of rapid reduction $(1 \mathrm{~d})$ and during the later slow reduction period $(15 \mathrm{~d})$. Dissolved ferric iron

Table 2. Saturation indices for predicted mineral solids.

\begin{tabular}{lcc}
\hline \multicolumn{1}{c}{ Solid } & Day $1^{\mathrm{a}}$ & Day $15^{\mathrm{a}}$ \\
\hline Ferrihydrite & 2.68 & 2.76 \\
Goethite & 5.38 & 5.46 \\
Lepidocrocite & 4.50 & 4.57 \\
Hematite & 13.17 & 13.31 \\
Magnetite & 19.43 & 19.18 \\
Green rust carbonate & 6.91 & 5.27 \\
Green rust chloride & -0.08 & -1.40 \\
Green rust sulfate & 5.81 & 5.07 \\
Siderite & 1.62 & 1.04 \\
Vivianite & 2.77 & -0.48 \\
Maghemite & 5.36 & 5.5 \\
Quartz & 0.17 & -0.28 \\
Hydroxyapatite & 2.84 & 0.87 \\
Calcite & 0.20 & 0.24 \\
\hline
\end{tabular}

Thermodynamic data from MINTEQA2 chemical speciation program; green rust values from Genin et al. (1998).

${ }^{\text {a }}$ SI values $>0$ saturated, $<0$ undersaturated, or $=0$ equilibrium with respect to phase. 


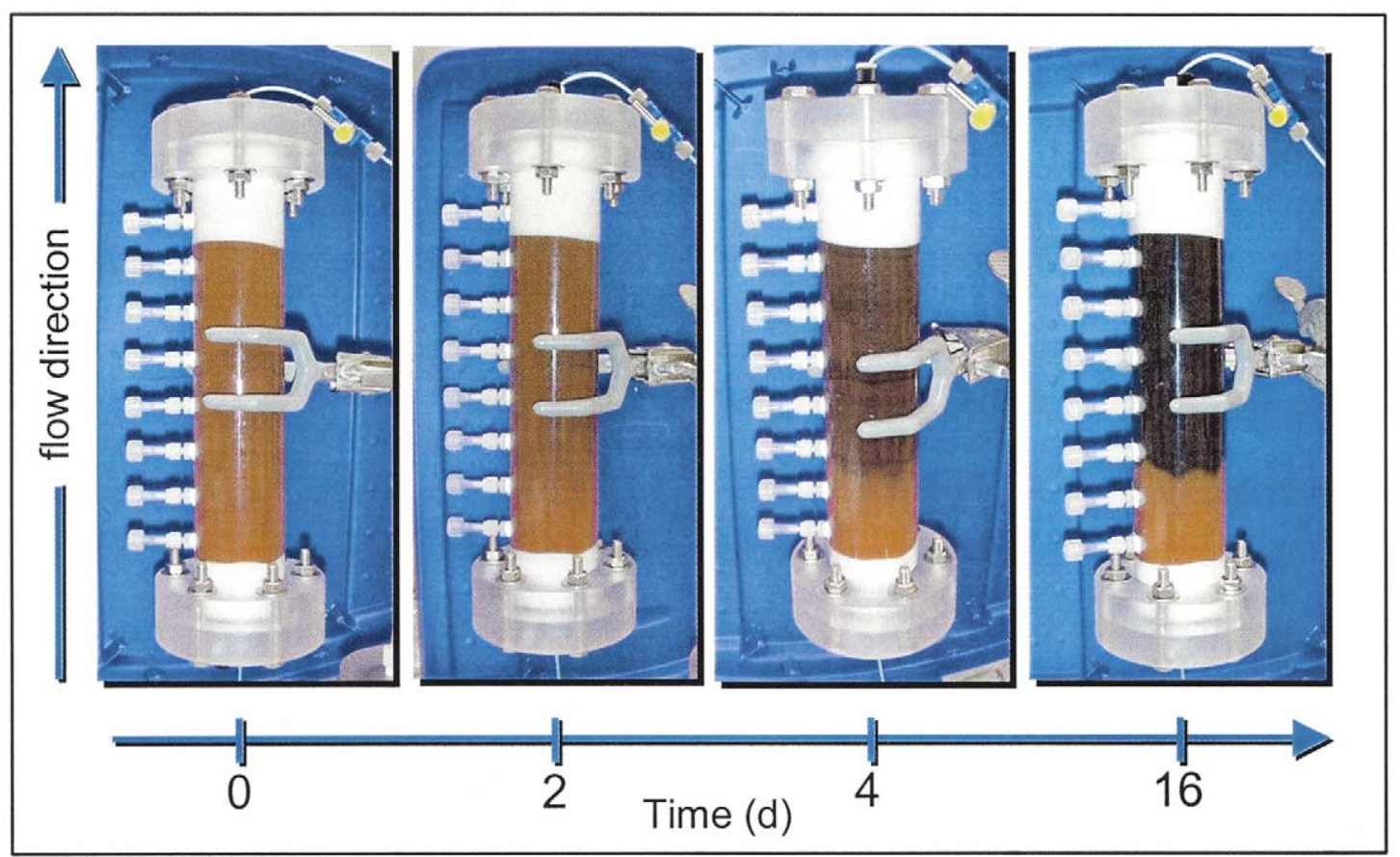

Fig. 1. Photographs of columns depicting visual solid-phase transformations over time.

Pore Volumes

concentrations were below level of detection for all samples; therefore, $\mathrm{Fe}(\mathrm{III})$ concentrations were estimated by equilibrium with the measured $\mathrm{Eh}$ and the $\mathrm{Fe}(\mathrm{II}) / \mathrm{Fe}(\mathrm{III})$ redox couple. The solubility constants for the green rust mineral phases were based on thermodynamic data of Genin et al. (1998).

\section{RESULTS}

\subsection{Biotic Column Studies}

The secondary mineralization of ferrihydrite was investigated using 2-line ferrihydrite-coated sand and S. putrefaciens under advective flow conditions. Three columns were run simultaneously and sequentially terminated to observe the progression of ferrihydrite conversion following reductive dissolution. Changes in microbial metabolism, aqueous chemistry, and solid-phase distributions were observed over time.

\subsubsection{Visual discoloration of Solid-Phase}

Visual changes in the solid-phase are evident both temporally and spatially within the column (Fig. 1). Within $2 \mathrm{~d}$ of reaction, the solids transform from orange (ferrihydrite) to brown within the upper two-thirds of the column (downgradient). Solids downgradient continue to darken to black over the course of the experiment; however, no visual discoloration of the solids occurs within the first $\sim 5 \mathrm{~cm}$ of the column (inflow) over the 16-d reaction period.

\subsubsection{Aqueous chemistry and microbial metabolites}

Influent lactate concentrations remain relatively constant at $\sim 3.3 \mathrm{mmol} / \mathrm{L}$ throughout the experiment (Fig. 2a). Effluent lactate concentrations, however, decrease to nearly $1 \mathrm{mmol} / \mathrm{L}$ after $12 \mathrm{~h}$ followed by a quick increase to $\sim 2.7 \mathrm{mmol} / \mathrm{L}$ after
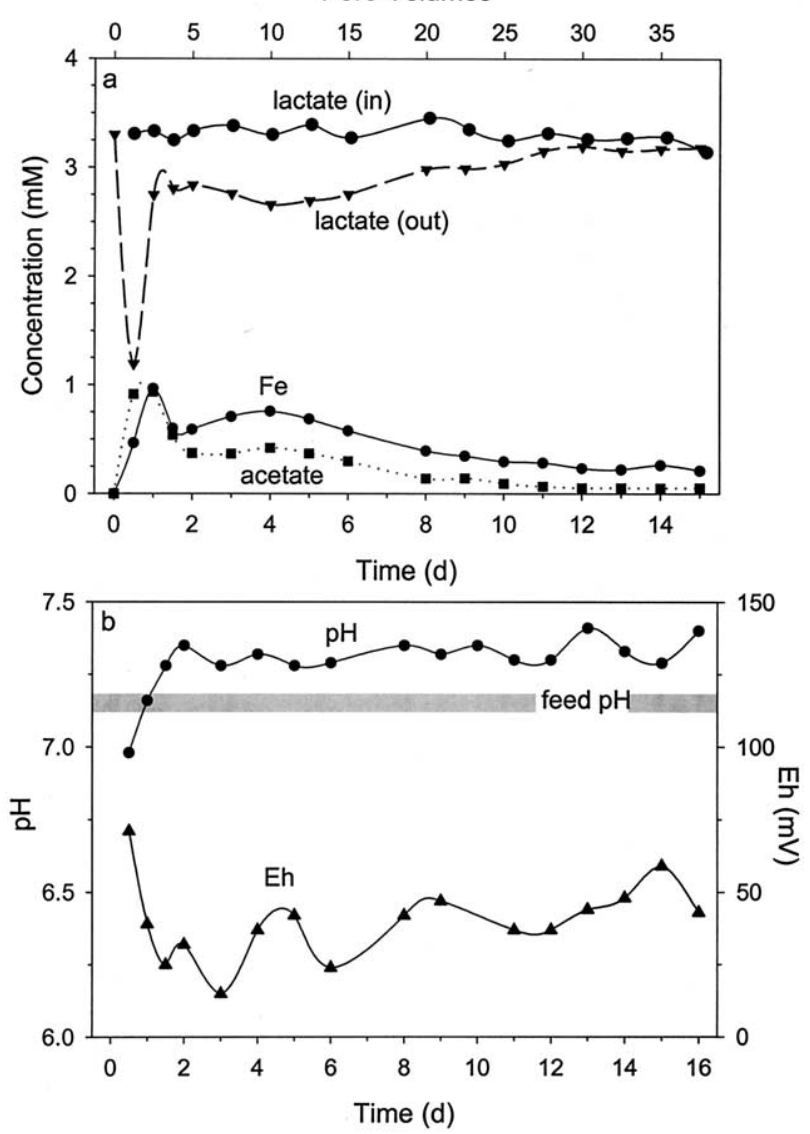

Fig. 2. (a) Influent (lactate) and effluent concentrations of lactate, acetate, and Fe throughout the course of the experiment (16 d). (b) Effluent $\mathrm{pH}$ and Eh values as a function of time. Eh values within the feed were maintained at $\sim 300 \mathrm{mV}$. 

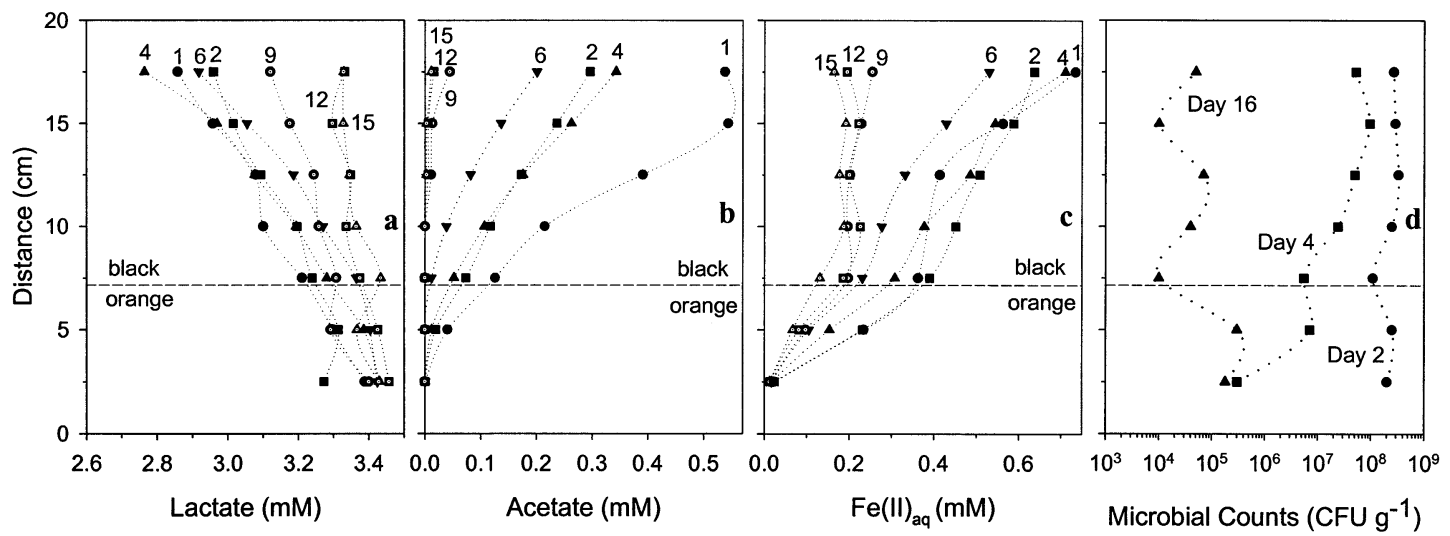

Fig. 3. (a) Lactate, (b) acetate, and (c) Fe concentrations along the length of the $16 \mathrm{~d}$ reacted column. Numbers adjacent to plots reflect the day of sampling. (d) Corresponding viable microbial cell distribution within the column over time.

another $12 \mathrm{~h}$ (24-h reaction period). From day 2 to 15 , the lactate concentrations gradually increase toward the influent concentration except for a gentle decline $(\sim 0.2 \mathrm{mmol} / \mathrm{L}$ fluctuation) centered at day 4 . Correspondingly, $\mathrm{Fe}$ and acetate concentrations mirror those of lactate. Concentrations of both constituents peak at $\sim 1 \mathrm{mmol} / \mathrm{L}$ after $1 \mathrm{~d}$ and then rapidly decline to $\sim 0.5 \mathrm{mmol} / \mathrm{L}$. A gradual increase is observed in $\mathrm{Fe}$ and acetate (peak at $4 \mathrm{~d}$ ) followed by a gentle decline until the termination of the experiment. An initial decline in $\mathrm{pH}$ is observed within the first day of reaction, corresponding to the production and subsequent sorption of ferrous iron (Fig. 2b). As a result of iron reduction, Eh values within the columns decline and are maintained between $\sim 25$ to $50 \mathrm{mV}$ over the course of the experiment.

Side port data illustrate the spatial distribution of processes within the column. Spatially, acetate and lactate concentrations mirror each other throughout the column (Fig. 3). Acetate concentrations decrease with a corresponding increase in lactate over the course of the experiment, and their profiles are nearly equivalent between 9 and $15 \mathrm{~d}$. These profiles reflect uniform removal of lactate and release of acetate to the pore water over the length of the column. In contrast, Fe concentration profiles change abruptly at $\sim 7 \mathrm{~cm}$ from the inflow throughout the course of the experiment, reflecting differential release of $\mathrm{Fe}$ to the pore water over the length of the column. Additionally, while the shape of acetate and lactate profiles are temporally similar, Fe profiles change substantially with time. The Fe(II) concentration profile changes between 6 and $9 \mathrm{~d}$ further downgradient. For the first $6 \mathrm{~d}, \mathrm{Fe}(\mathrm{II})$ concentrations continue to increase downgradient; however, after 9 d, Fe(II) levels are constant throughout the downfield portion of the column. Also of note are the low Fe(II) concentrations at the bottom (inflow) of the column; ferrous iron concentrations average $0.02 \mathrm{mmol} / \mathrm{L}$ within the first $\sim 3 \mathrm{~cm}$ of the column throughout the experiment.

\subsubsection{Microbial distribution and growth}

Initially, bacterial surface coverage and numbers were uniform over the length of the column. Following inoculation, bacterial cells covered $\sim 70$ to $80 \%$ of the ferrihydrite surface. Over the course of $16 \mathrm{~d}$, microbial numbers decrease several orders of magnitude within the columns (Fig. 3d). After $2 \mathrm{~d}$, the microbial community is uniformly distributed in the column having $\sim 10^{8}$ colony forming units (CFU) $\mathrm{g}^{-1}$. Two days later, the microbial numbers decrease an order of magnitude throughout the column, except for the inlet section, which decreases nearly 3 orders of magnitude. Following $16 \mathrm{~d}$, the microbial distribution ranges from $10^{5}$ to $10^{4} \mathrm{CFU} \mathrm{g}^{-1}$. However, the inlet section of the column does not substantially decrease in microbial numbers between 4 and $16 \mathrm{~d}$.

\subsubsection{Biogenic solids}

The progression of Fe phase transformations was monitored both temporally and spatially throughout the column using a suite of spectroscopic and microscopic techniques. The distribution of total solid-phase Fe remains relatively homogeneously distributed over time; minimal Fe is transported downgradient (Fig. 4) suggesting localized transformations and neither redistribution from dissolution/reprecipitation downgradient nor colloidal transport. Phosphorous concentrations associated with the solids increase temporally with a substantial accumulation at the influent end of the column. Within the initial $2 \mathrm{~cm}$ of the column, $\mathrm{P}$ increases $>1$ order of magnitude (0.004-0.047 $\mathrm{mg} \mathrm{kg}^{-1}$ ) between day 4 and 16. Similarly, while $\mathrm{Ca}$ appears to decrease elsewhere in the column, concentrations increase with time within the initial $2 \mathrm{~cm}$.

The identification and quantification of secondary minerals produced following ferrihydrite reduction was obtained by per-

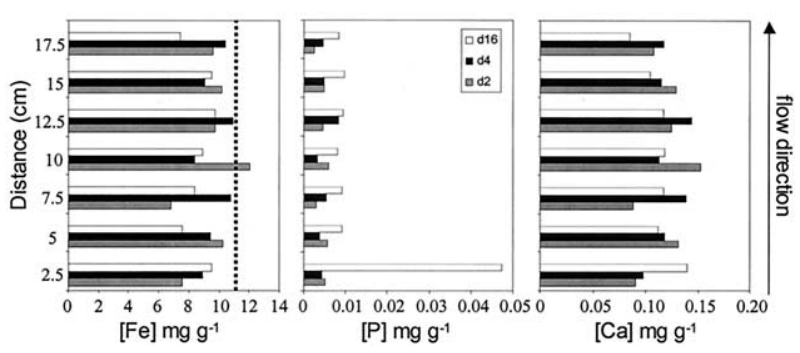

Fig. 4. Concentrations of (a) Fe, (b) P, and (c) Ca within the solid-phase determined by acid digestion. Solid vertical line represents starting Fe concentration. 


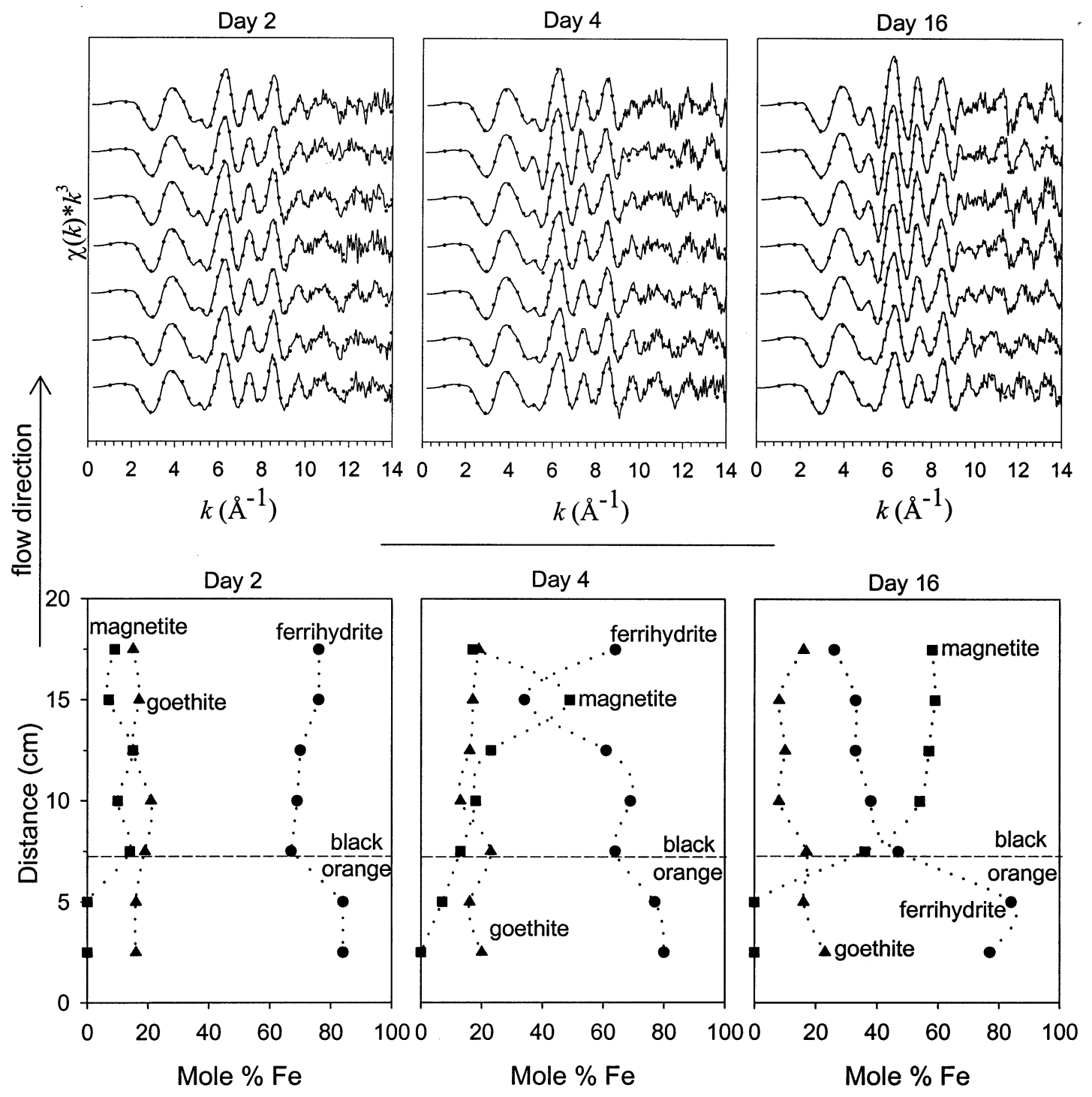

Fig. 5. (a) $k^{3}$-weighted EXAFS spectra (solid line) and linear-combination fit (dotted line) for the solid-phase products throughout the column for three time periods. (b) Corresponding percents of mineral obtained from linear-combination fits of $k^{3}$-weighted EXAFS spectra. All percents are $\pm 5 \%$ and the detection limit is $\sim 5 \%$. The dashed line represents the contact between the visual orange and black solids within the column.

forming linear combinations fitting of $k^{3}$-weighted EXAFS spectra. Substantial mineral phase transformations are observed within the column, with ferrihydrite conversion to predominantly goethite and magnetite (Fig. 5). After $2 \mathrm{~d}$ of reduction, goethite concentrations range from 15 to $21 \%$. Following additional reduction, the proportion of goethite remains relatively constant, ranging from 13 to $23 \%$ at $4 \mathrm{~d}$ and 8 to $23 \%$ after 16 d. Magnetite, however, continues to increase through time, peaking at $59 \%$ following $16 \mathrm{~d}$ of reaction. Thus, goethite formation ceases and magnetite increases beyond $4 \mathrm{~d}$ of reduction with the proportions of magnetite mirroring those of ferrihydrite. Conversely, magnetite accumulation is not observed even after $16 \mathrm{~d}$ at the bottom (inflow) of the column.

Secondary mineralization of ferrihydrite to goethite and magnetite was confirmed by Mössbauer spectroscopy (Fig. 6). Mössbauer spectra for the initial $2 \mathrm{~cm}$ of the column reacted for
$2 \mathrm{~d}$ have an intense doublet dominating the spectra, consistent with that of ferrihydrite (Fig. 6a). The presence of a small $(<5 \%)$ ferrous-bearing solid is indicated by the high energy peak of the ferrous doublet. Absence of a sextet feature in the spectrum indicates that goethite present in the sample is $<\sim 15$ $\mathrm{nm}$ (Jonot et al., 1973). Farther downgradient within the 2-d column (Fig. 6b), conversion of ferrihydrite to goethite and magnetite are indicated by the addition of poorly resolved sextets typical of tetrahedral and octahedral $\mathrm{Fe}$ in a magnetitelike solid (McNab et al., 1968). To resolve the biogenic products after $16 \mathrm{~d}$ of reaction, simulations of the Mössbauer spectra were performed (Figs. $6 \mathrm{c}$ and $6 \mathrm{~d}$ ). Increased proportions of magnetite are evident by the enhanced sextet features in the Mössbauer spectrum (McNab et al., 1968). Small particle goethite may display either a doublet feature or a "collapsed" sextet in the Mössbauer spectrum making it difficult to quantify 

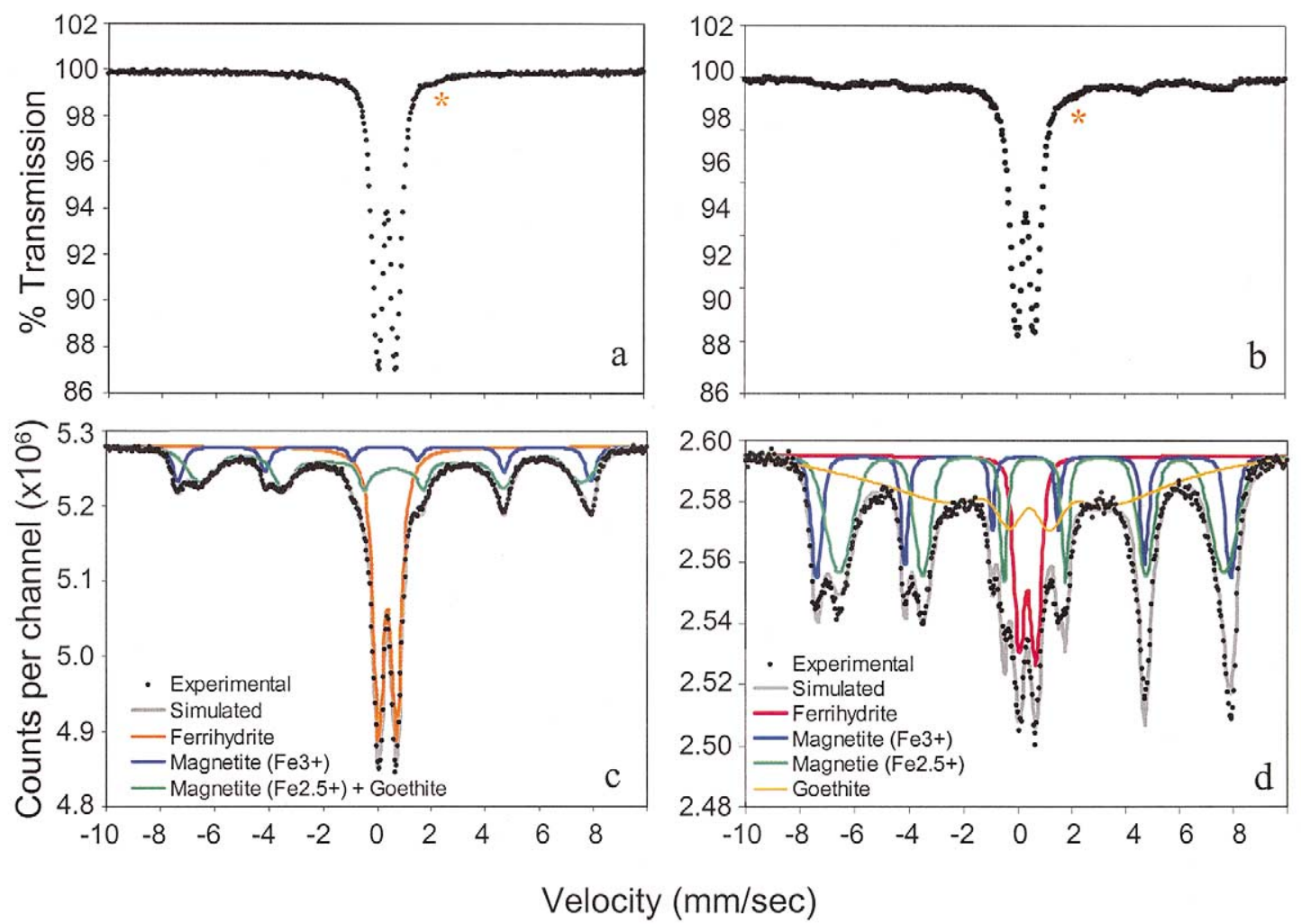

Fig. 6. Mössbauer spectrum of biomineralization solids from the (a) bottom ( $3 \mathrm{~cm}$ from inlet) and (b) top (3 $\mathrm{cm}$ from outlet) of the column reacted for $2 \mathrm{~d}$ and (c) middle $(7 \mathrm{~cm}$ from inlet) and (d) top ( $3 \mathrm{~cm}$ from outlet) of the column reacted for $16 \mathrm{~d}$. The high energy peak of the ferrous doublet for the samples from the $2 \mathrm{~d}$ column are denoted by "**." The simulated fit (solid lines) to the experimental spectra (dotted) are shown for the column reacted for $16 \mathrm{~d}$.

in the presence of ferrihydrite and magnetite (Bocquet et al., 1992). While quantification of the three constituents is complicated due to the small particle size of goethite (see below), Mössbauer analysis is consistent (within 2-15\%) with the results obtained from EXAFS spectroscopy.

Transmission electron microscopy further confirms the presence of goethite and magnetite and illustrates the small particle size and spatial orientations of the products. Goethite is predominantly associated with the surface of ferrihydrite (Fig. 7a); minor amounts are associated with the microbial cell surface (Fig. 7b). Goethite crystals appear to encrust a small fraction $(\sim 10 \%)$ of bacterial cells with the laths oriented tangentially to the cell surface. The distribution of goethite varies between grains (i.e., abundant goethite crystals may be associated with one ferrihydrite-coated sand grain but not on an adjacent grain) (Fig. 7c). Goethite crystals average $\sim 10 \mathrm{~nm}$ in width and 80 $\mathrm{nm}$ in length and have a lath-like crystal habit (Fig. 7d). Magnetite crystals average $\sim 50 \mathrm{~nm}$ and display both cubic and botryoidal crystal habits (Fig. 7e) and are associated with the ferrihydrite surface and not the cell envelope (Figs. $7 \mathrm{f}$ and $7 \mathrm{~g}$ ). Small magnetite nucleation sites $(\sim 10 \mathrm{~nm})$ are evident throughout the ferrihydrite with larger crystals $(\sim 50 \mathrm{~nm})$ on the ferrihydrite surface. Minor $(<5 \%)$ amounts of green rust are also identified based on crystal morphology by SEM, potentially explaining the high energy peak of the ferrous doublet in the Mössbauer spectra for the 2-d solids. Green rust solids consist of hexagonal layered plates ranging from 0.5 to $1 \mu \mathrm{m}$ in width that stack normal to the (0001) face of the prism (data not shown).

\subsubsection{Geochemical modeling}

Saturation indices were computed for the pore waters (Table 1) with respect to the observed Fe(II/III) phases. Although the mineral saturation data are compromised by the uncertainty regarding $\mathrm{Fe}(\mathrm{III})$ activity and the likelihood that nonequilibrium conditions exist within the column, the data do provide information on the relative thermodynamic driving forces influencing mineral phases within the column. Iron(III) activity is fixed by the measured Eh and assuming equilibrium with the ferric/ferrous redox couple. Calculated saturation indices indicate the effluent water is near equilibrium or supersaturated for many mineral phases including siderite $\left(\mathrm{FeCO}_{3}\right)$, ferrihydrite $\left(\mathrm{Fe}_{2} \mathrm{O}_{3} \cdot \mathrm{nH}_{2} \mathrm{O}\right)$, goethite $(\alpha-\mathrm{FeOOH})$, lepidocrocite $(\gamma$ $\mathrm{FeOOH})$, hematite $\left(\alpha-\mathrm{Fe}_{2} \mathrm{O}_{3}\right), \quad$ green rust $\left(\left[\mathrm{Fe}^{\mathrm{II}}{ }_{(6-\mathrm{x})} \mathrm{Fe}^{\mathrm{III}}{ }_{\mathrm{x}}(\mathrm{OH})_{12}\right]^{\mathrm{x}+}\left[\left(\mathrm{A}^{2-}\right)_{\mathrm{x} / 2} \cdot \mathrm{yH}_{2} \mathrm{O}\right]^{\mathrm{x}-}\right)$, and magnetite $\left(\mathrm{Fe}_{3} \mathrm{O}_{4}\right)$ (Table 2). Despite apparent supersaturated conditions for all of these phases, only magnetite and goethite accumulate in appreciable amounts within the columns.

\subsection{Abiotic Batch Studies}

The role of bacteria in the secondary mineralization of ferrihydrite to goethite and magnetite was isolated by abiotically 

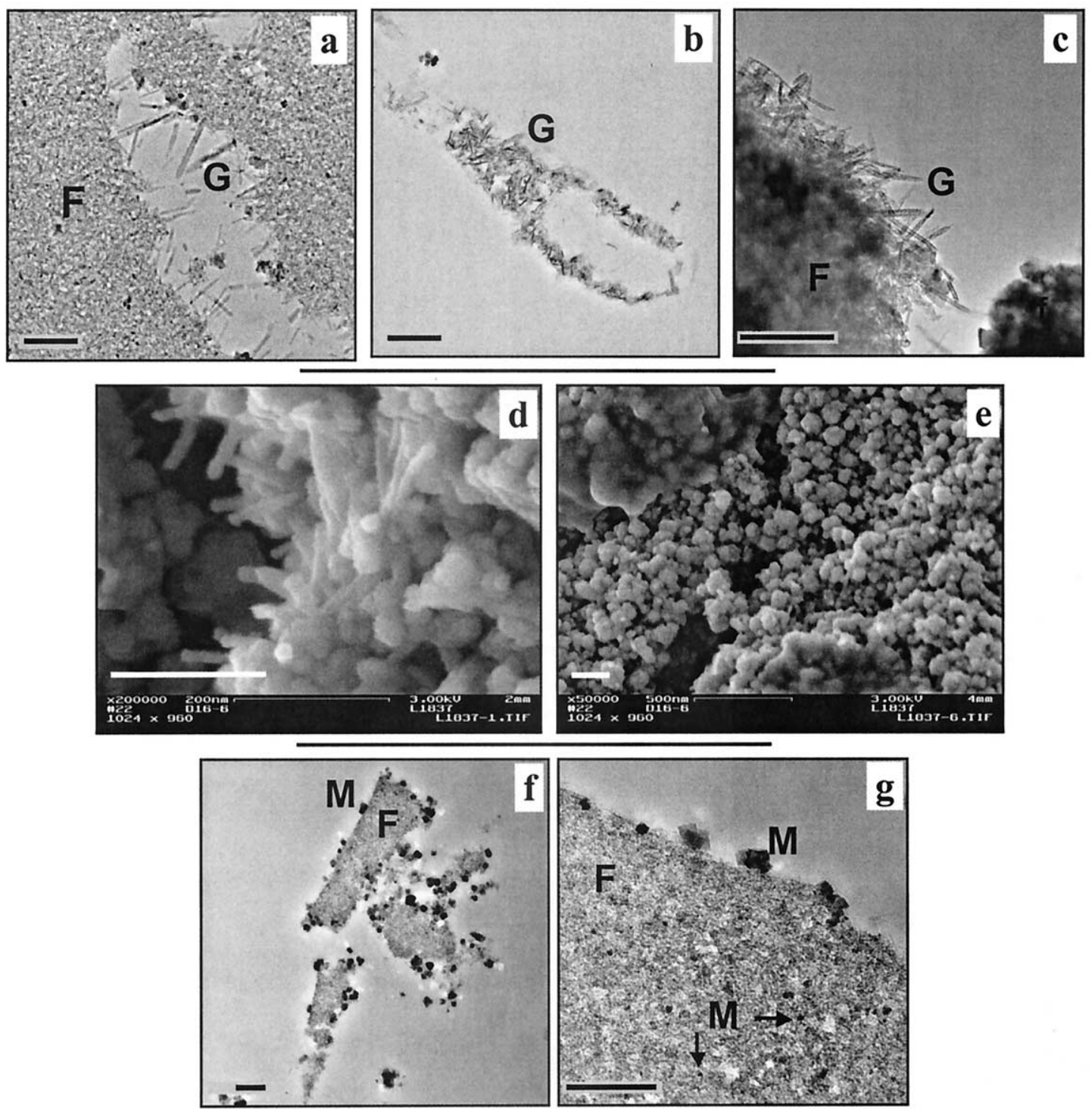

Fig. 7. TEM and SEM images of goethite and magnetite secondary phases. TEM images of goethite reveal (a) perpendicular goethite $(\mathrm{G})$ laths to the ferrihydrite (F) surface (top of 2-d column), (b) an oblique cross-section through a goethite-encrusted bacterium (top 4-d column), and (c) whole-mount of two ferrihydrite grains, one encrusted in goethite (top 16-d column). SEM images of (d) goethite and (e) magnetite (M) display their bulk morphology and small particle size. Also illustrated are TEM images of magnetite precipitates originating from the ferrihydrite surface isolated from the effluent end of the $4 \mathrm{~d}$. (f, g) Arrows in the TEM image point to small magnetite nucleation sites within the ferrihydrite. All images shown are representative of the samples as a whole. Scale bars are equal to $200 \mathrm{~nm}$.

reacting Fe(II) with 2-line ferrihydrite-coated sand. These experiments also elucidate differences between biotic and abiotic secondary precipitates and provide information on the kinetics of ferrihydrite conversion.

\subsubsection{Role of $\mathrm{Fe}(\mathrm{II})$ concentration}

Abiotic reactions of ferrous Fe with 2-line ferrihydrite illustrates the importance of $\mathrm{Fe}(\mathrm{II})$ concentration on the secondary minerals produced. Following $9 \mathrm{~d}$, reaction of ferrous iron with 2-line ferrihydrite-coated sand results in the precipitation of goethite, lepidocrocite, and magnetite (Fig. 8). With increasing initial $\mathrm{Fe}(\mathrm{II})$ concentrations, a mineral phase progression is observed from unaltered ferrihydrite to goethite/lepidocrocite to goethite/magnetite precipitation. The addition of as little as $0.04 \mathrm{mmol} / \mathrm{L} \mathrm{Fe}$ (II) leads to the conversion of nearly half of the ferrihydrite to the more stable iron hydroxide phases, goethite and lepidocrocite within $9 \mathrm{~d}$ of reaction. Conversely, in the absence of dissolved Fe(II), no mineral changes are observed. Magnetite precipitation is not detected below $0.4 \mathrm{mmol} / \mathrm{L}$ $\mathrm{Fe}$ (II) (equivalent to $1.0 \mathrm{mmol} \mathrm{Fe}[\mathrm{II}] / \mathrm{g}$ ferrihydrite) following $9 \mathrm{~d}$ but becomes appreciable (increasingly so) above this threshold-levels peak at $\sim 65 \%$ at $2 \mathrm{mmol} / \mathrm{L} \mathrm{Fe}(\mathrm{II})$. Goethite/ lepidocrocite concentrations peak at $\sim 70 \%$ but decline to $\sim 25 \%$ upon magnetite precipitation. 


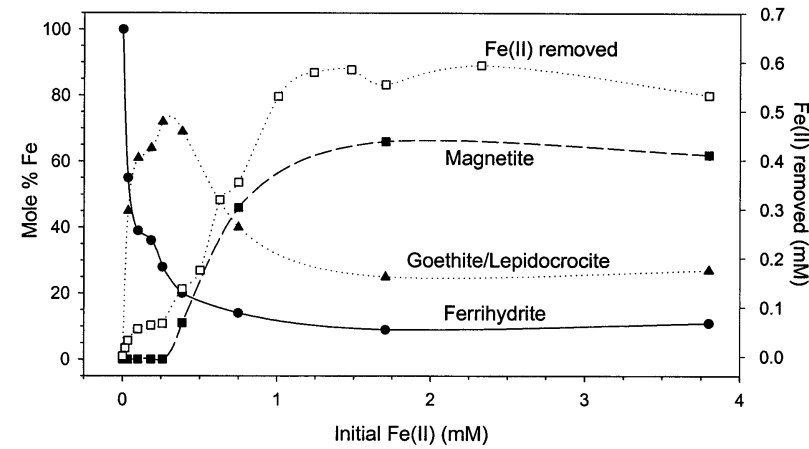

Fig. 8. Secondary mineralization as a function of initial $\mathrm{Fe}$ (II) concentrations. Reactions involved the addition of 0 to $4.6 \mathrm{mmol} / \mathrm{L}$ ferrous chloride to 2-line ferrihydrite-coated sand for $9 \mathrm{~d}$. The open squares plot is the $\mathrm{Fe}$ (II) removed from solution following 9-d reaction with ferrihydrite. Percentages were determined from linear combination fits of $k^{3}$-weighted Fe EXAFS spectra $(k=1-14)$.

The presence of lepidocrocite in the abiotic systems but not the biotic systems is, most likely, due to either high chloride concentrations or lack of carbonate (Cornell and Schwertmann, 1996). Lepidocrocite is not detected as a secondary phase following reaction of $2 \mathrm{mmol} / \mathrm{L}$ ferrous sulfate with 2-line ferrihydrite for $9 \mathrm{~d}$ both in the presence or absence of carbonate (data not shown).

\subsubsection{Precipitation kinetics}

The differences in precipitation rates between goethite and magnetite were examined using $2 \mathrm{mmol} / \mathrm{L}$ ferrous sulfate (sulfate used to avoid lepidocrocite precipitation) and 2-line ferrihydrite-coated sand. In the presence of $2 \mathrm{mmol} / \mathrm{L} \mathrm{Fe}(\mathrm{II})$, conversion of 2-line ferrihydrite to goethite is rapid, with nearly $60 \%$ conversion within $2 \mathrm{~h}$ (Fig. 9). Goethite precipitation continues, peaking at $\sim 70 \%$, until magnetite forms. Magnetite is detected following $12 \mathrm{~h}$ and accumulates at a substantially

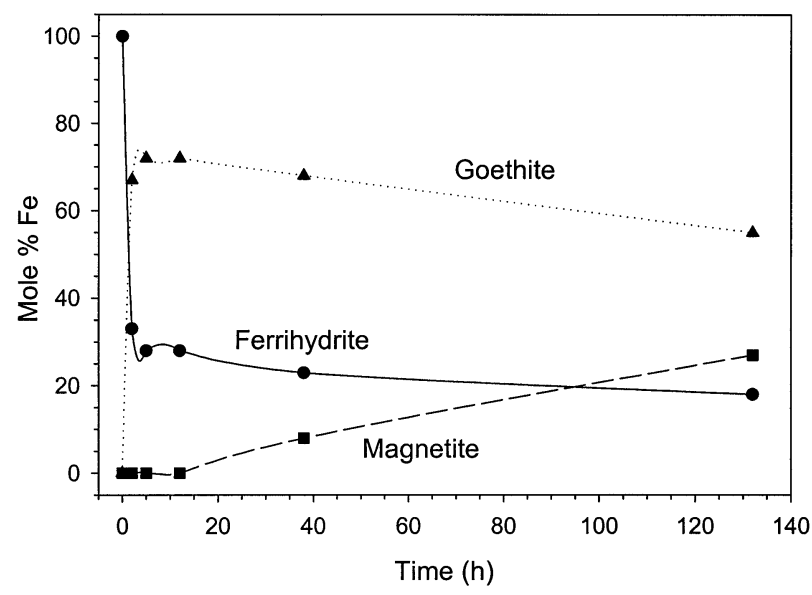

Fig. 9. Conversion rates of 2-line ferrihydrite-coated sand to goethite and magnetite in the presence of $2 \mathrm{mmol} / \mathrm{L}$ ferrous sulfate. Percentages were determined from linear combination fits of $k^{3}$-weighted Fe EXAFS spectra $(k=1-14)$. slower rate than goethite. Over time, the proportion of magnetite increases at the expense of both ferrihydrite and goethite.

\subsubsection{Crystal size and morphology}

Similar to the biotic systems, magnetite and goethite are associated with ferrihydrite. In contrast, the crystals formed in the abiotic experiments are much larger ( $>10$-fold) than those observed in the biotic column experiments. Goethite crystals average 50 to $100 \mathrm{~nm}$ in width and 100 to $300 \mathrm{~nm}$ in length and are polydomainic, commonly displaying star-like twins originating from a ferrihydrite core (Fig. 10a). Magnetite particles consist of intergrown crystals averaging $500 \mathrm{~nm}$ in diameter with ferrihydrite fringes (Fig. 10b). Lepidocrocite grains are much larger than those of goethite and magnetite, averaging a few micrometers in length (Fig. 10c).

\section{DISCUSSION}

\subsection{Microbial Metabolism}

The introduction of $S$. putrefaciens strain $\mathrm{CN} 32$ to 2-line ferrihydrite-coated sand under advective flow results in the oxidation of lactate to acetate coupled to $\mathrm{Fe}(\mathrm{III})$ reduction. Three periods of activity are noted: (1) increased acetate and $\mathrm{Fe}(\mathrm{II})$ concentrations reflecting intense microbial activity, (2) decreased acetate and $\mathrm{Fe}(\mathrm{II})$ production consistent with decreasing microbial metabolism, and (3) stable acetate and Fe(II) concentrations representing a quasi-equilibrium controlled by secondary phase conversion and dissolution (Fig. 2a). The period of enhanced acetate production corresponds with a darkening of the solid-phase from orange (ferrihydrite) to brown (4 d) (Fig. 1). The solids continue to darken, eventually to black, until termination of the column experiments (16 d) (Fig. 1). Iron respiration coupled to incomplete lactate oxidation results in the production of 4 mole of $\mathrm{Fe}$ (II) for every mole of acetate generated (reaction 1):

$$
\begin{aligned}
4 \mathrm{Fe}(\mathrm{OH})_{3}+\mathrm{CH}_{3} \mathrm{CHOHCOO}^{-}+7 \mathrm{H}^{+} & \\
= & 4 \mathrm{Fe}^{2+}+\mathrm{CH}_{3} \mathrm{COO}^{-}+\mathrm{HCO}_{3}^{-}+10 \mathrm{H}_{2} \mathrm{O}
\end{aligned}
$$

The measured ratio of aqueous $\mathrm{Fe}$ (II) to acetate (Fig. 2a), however, is well below 4 during the first $10 \mathrm{~d}$ of the experiment, indicating that $\mathrm{Fe}$ (II) is being sequestered within the solid-phase.

The onset of microbial respiration results in an initial decline in $\mathrm{pH}$ due to exchange between microbially-generated ferrous iron and protons on the ferrihydrite surface (Fig. 2b). Once the ferrihydrite sorption capacity is attained, however, continued microbial respiration results in a moderate increase in $\mathrm{pH}$ throughout the column, consistent with reaction 1 above.

\subsection{Secondary Phase Formation Following Fe(III) Reduction}

\subsubsection{Secondary phases}

The solid-phase products formed during dissimilatory iron reduction of ferrihydrite are goethite and magnetite, with minor amounts of green rust also noted (Figs. 5-7). After $16 \mathrm{~d}$ of reduction, magnetite is the dominant solid-phase product. The magnitude of $\mathrm{Fe}(\mathrm{II})$ sequestration within magnetite can be 

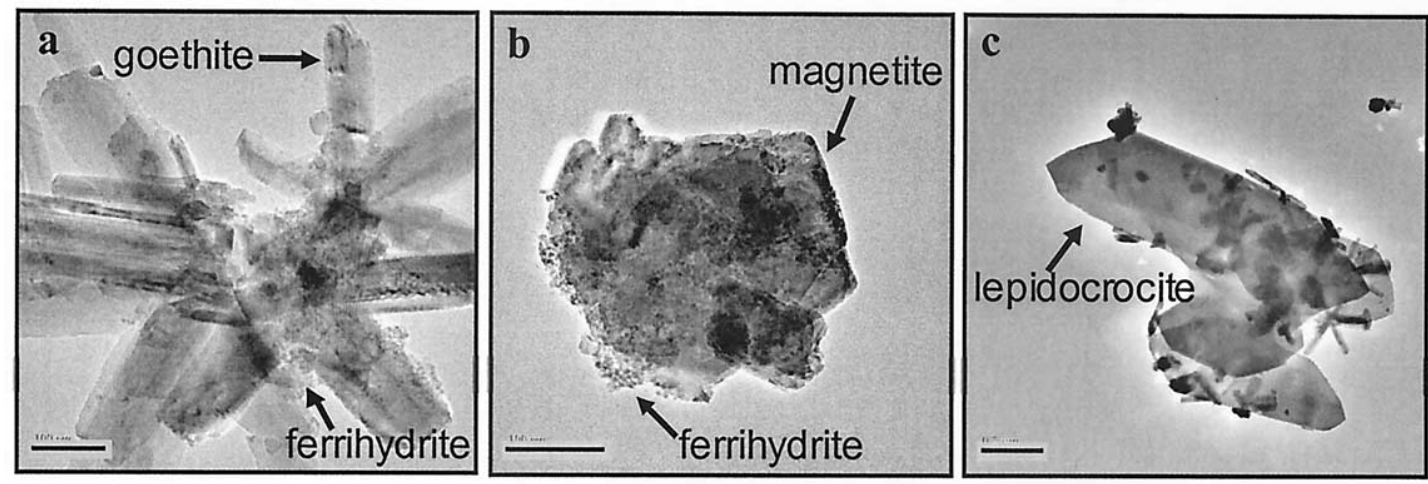

Fig. 10. Transmission electron images of (a) goethite, (b) magnetite, and (c) lepidocrocite crystals formed abiotically. Minerals were formed following $9 \mathrm{~d}$ of reaction of ferrous chloride with 2-line ferrihydrite-coated sand (corresponds with data from Fig. 7). Equivalent sizes and morphologies for goethite and magnetite were obtained using ferrous sulfate as the Fe(II) source. Scale bar on (a) and (b) is $100 \mathrm{~nm}$ and $500 \mathrm{~nm}$ for (c).

determined by an iron mass balance. The total amount of aqueous $\mathrm{Fe}(\mathrm{II})$ produced is deduced by considering a 4:1 stoichiometry (Eqn. 1 above) between Fe(II) and acetate production. On the basis of acetate concentrations, $16.2 \mathrm{mmol}$ of $\mathrm{Fe}(\mathrm{II})$ are produced within the column over $16 \mathrm{~d}$ of which 10.4 $\mathrm{mmol}$ of $\mathrm{Fe}(\mathrm{II})$ are eluted. Thus, $5.8 \mathrm{mmol}$ of $\mathrm{Fe}(\mathrm{II})$ are sequestered within the solid-phase. Of the $40.6 \mathrm{mmol}$ total Fe, magnetite contains $5.1 \mathrm{mmol}$ of $\mathrm{Fe}$ (II) (on the basis of magnetite percentages obtained from EXAFS linear combination fits). The Fe(II) difference $(0.7 \mathrm{mmol})$ may be attributed to minor solid-phase constituents (e.g., green rust) or sorption to either the mineral or bacterial surfaces. Magnetite, therefore, is the dominant (88\%) sink for Fe(II), as well as an appreciable (29\%) secondary source of $\mathrm{Fe}(\mathrm{III})$, within the system. Moreover, goethite contains $\sim 16 \%$ of the $\mathrm{Fe}(\mathrm{III})$ after $16 \mathrm{~d}$ of reduction.

Green rust is observed as a transitory minor phase following initial reduction. Previous investigations of secondary precipitation following 2-line ferrihydrite reduction by $S$. putrefaciens observed the formation of green rust only in the presence of phosphate and AQDS, resulting in inhibition of magnetite formation and allowing the ratio of $\mathrm{Fe}(\mathrm{II}) / \mathrm{Fe}$ (III) to exceed 2 or more (Fredrickson et al., 1998). Green rust is not observed in the 4 or $16 \mathrm{~d}$ columns, suggesting that it forms as an initial product of reduction and may undergo subsequent dissolution and/or conversion. Although it exists at a concentration $<5 \%$ within this system, by way of its high reactivity it may constitute a major control on solution and solid-phase equilibria as well as the fate of redox-active contaminants during the early stages of biomineralization.

\subsubsection{Mineral associations and precipitation mechanisms}

As revealed in the microscopic images (Fig. 7), both goethite and magnetite are associated with the ferrihydrite surface. This relationship corresponds with the plausible mechanisms of goethite and magnetite mineralization from ferrihydrite. Magnetite crystals are exclusively associated with the ferrihydrite surface and not the microbial cell envelope (Figs. $7 \mathrm{f}$ and $7 \mathrm{~g}$ ), thus suggesting that the microbial cell is only indirectly (ferrous iron source) responsible for magnetite precipitation. The association of magnetite with ferrihydrite is consistent with nucleation via solid-state conversion of ferrihydrite driven by $\mathrm{Fe}(\mathrm{II})$ sorption (Cornell, 1988; Tronc et al., 1992; Fredrickson et al., 1998).

Goethite crystals are also primarily associated with the ferrihydrite surface (Figs. 7a and 7c). In the presence of ferrihydrite, goethite forms by either aggregation-based crystal growth (Banfield et al., 2000) or Ostwald ripening of ferrihydrite (dissolution/reprecipitation) (Cornell and Schwertmann, 1996). Goethite crystals originate from ferrihydrite growing perpendicular to the surface, indicative of a dissolution/reprecipitation growth mechanism. Due to the instability of ferrihydrite, conversion (Ostwald ripening) to thermodynamically more stable goethite may also occur in the absence of aqueous $\mathrm{Fe}(\mathrm{II})$. However, the time required for such conversion at room temperature is weeks to months (Benner et al., 2002; Zachara et al., 2002), not $<2 \mathrm{~d}$ as we observe here. Sorbed ferrous Fe, however, catalyzes Ostwald ripening of ferrihydrite to goethite (Cornell and Schwertmann, 1996; Zachara et al., 2002).

While goethite crystals are predominantly associated with ferrihydrite, deposition on the microbial cell surface is also noted (Fig. 7b). The role of the microbial cell, whether it be direct or indirect, in goethite precipitation is unknown. Recently, microcrystalline goethite was added to a suspension of S. putrefaciens $\mathrm{CN} 32$ where the crystals ultimately became oriented in a manner similar to that observed here; the long axis (c-axis) of the goethite crystal was aligned tangentially to the cell surface (Glasauer et al., 2001). The outer membrane of $S$. putrefaciens contains rough lipopolysaccharides (i.e., no $\mathrm{O}$ side chains) suggesting that the phosphoryl residues are the dominant binding sites. Due to the high affinity of iron (hydr)oxides for phosphate, strong complexation between phosphoryl residues on the cell surface and goethite crystals is plausible. Accordingly, the association of goethite with the microbial cell may either be a result of heterogeneous precipitation on the cell surface or heterogeneous precipitation on ferrihydrite followed by electrostatically-induced (negatively charged cell wall sidechains and positively charged mineral surface) sorption of dislodged goethite crystals to the microbial cell. 



Fig. 11. Transmission electron micrographs comparing the crystal size and morphology of goethite and magnetite within the biotic and abiotic systems. Scale bar represents $200 \mathrm{~nm}$ for the goethite images and $50 \mathrm{~nm}$ for magnetite.

\subsubsection{Bacterial role in precipitation}

The role of bacteria in the secondary mineralization of goethite and magnetite from ferrihydrite was investigated by abiotically reacting ferrous iron with ferrihydrite (Fig. 8). Reaction of $2 \mathrm{mmol} / \mathrm{L}$ ferrous iron with ferrihydrite for $9 \mathrm{~d}$ results in the near-complete conversion of ferrihydrite to goethite $(26 \%)$ and magnetite $(62 \%)$. The abiotic formation of goethite and magnetite further supports the aforementioned explanations for secondary mineralization within the biotic columns. Though controlled intracellular precipitation of iron oxides by $S$. putrefaciens was recently reported (Glasauer et al., 2002), only extracellular precipitation is observed in this research. Nevertheless, while bacteria appear to primarily serve as an Fe(II) source, crystal growth is restricted within the biotic systems compared to the abiotic systems (Fig. 11). Abiotically produced crystals are polydomainic and $\sim 10$-fold larger than those formed in the biotic system. This observation may be explained by the truncation of crystal growth in the presence of organic molecules and/or inorganic ligands (Inskeep and Bloom, 1986; Grossl and Inskeep, 1992; Hoch et al., 2000).

\subsection{Factors Influencing Operating Mineralization Pathways}

Although magnetite and goethite are the dominant secondary solid-phase products, their temporal accumulation and spatial distribution in the column experiments varies (Fig. 5). After $2 \mathrm{~d}$ of reduction, goethite is the principal secondary phase, having a nearly homogenous distribution throughout the column. Goethite concentrations throughout the column remain constant over time. Conversely, magnetite concentrations are initially low but increase temporally in the downgradient regions. The secondary mineralization pathways are a result of multiple interactive processes (addressed below), which ultimately dictate the operating biomineralization pathway.

\subsubsection{Ferrous Fe concentration}

Following reductive dissolution of ferrihydrite, the secondary precipitation of goethite and magnetite is controlled predominantly by ferrous iron concentration and supply rate (Zachara et al., 2002). As discussed above, the proposed 

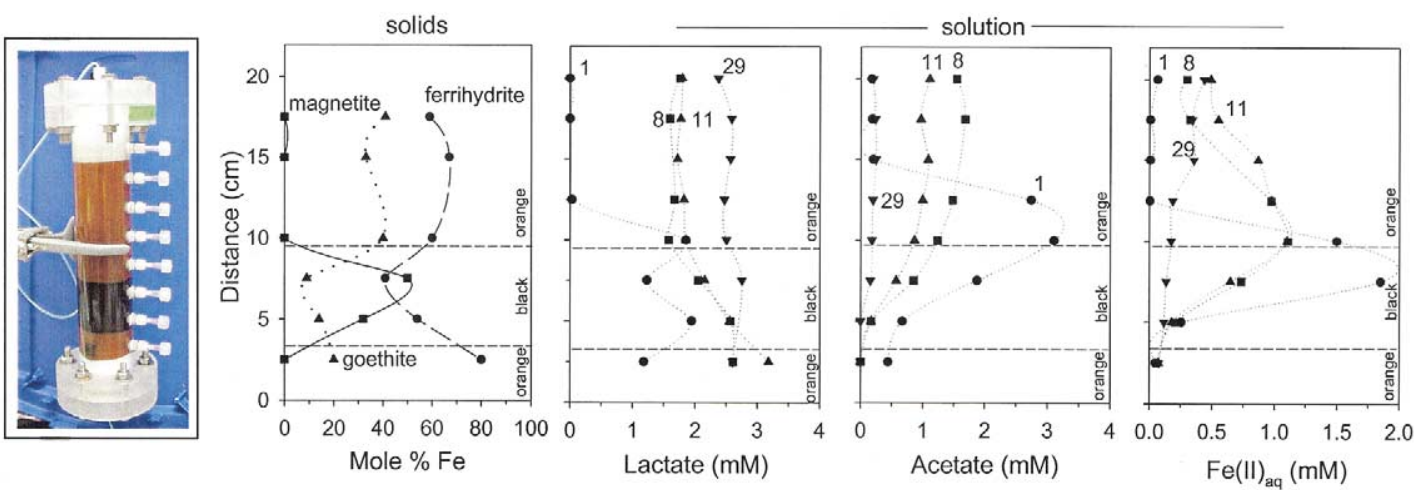

Fig. 12. Lactate, acetate, and Fe concentration profiles along the length of the slower flow $\left(0.1 \mathrm{~m} \mathrm{~d}^{-1}\right)$ columns. Numbers adjacent to plots reflect the day of sampling. Visual discoloration of the solid-phase is depicted in the picture (left) and reflects a dramatically different solid-phase distribution than the faster flow $\left(0.6 \mathrm{~m} \mathrm{~d}^{-1}\right)$ columns (refer to Fig. 1$)$.

precipitation mechanisms for goethite (dissolution/reprecipitation) and magnetite (solid-state conversion) initiate with Fe(II) sorption to ferrihydrite. Correspondingly, Fe(II) profiles support the observed solid-phase distributions (Figs. 3 and 5). Aqueous $\mathrm{Fe}$ (II) concentrations decline at $\sim 7 \mathrm{~cm}$ from the inflow, which corresponds with the visual discoloration of the solids from orange to black and mineralogical composition. Considering that the rate of ferrihydrite reduction remains constant spatially and temporally, as indicated by the linear acetate profiles (Fig. 3b), the observed decrease in Fe(II) gradient indicates that the majority of $\mathrm{Fe}(\mathrm{II})$ is sequestered in the solid-phase downfield from the orange-black boundary $(\sim 7$ $\mathrm{cm}$ ). Due to the uniform distribution of goethite, magnetite is apparently the dominant control on $\mathrm{Fe}(\mathrm{II})$ concentrations.

Further investigation of the $\mathrm{Fe}(\mathrm{II})$ profiles (Fig. 3c) lends insight into the secondary mineralization processes. Ferrous iron concentrations peak at $\sim 0.85 \mathrm{mmol} / \mathrm{L}$ within the latter (downgradient) two-thirds of the column, consistent with higher levels of magnetite accumulation. Conversely, within the initial $5 \mathrm{~cm}$ of the column where magnetite precipitation is absent, $\mathrm{Fe}$ (II) concentrations do not exceed $0.3 \mathrm{mmol} / \mathrm{L}$ (Figs. $3 \mathrm{c}$ and 5). This boundary may therefore represent a threshold $\mathrm{Fe}(\mathrm{II})$ concentration required for magnetite nucleation (initial magnetite crystallization following Fe(II) sorption). An equivalent threshold value was observed in the abiotic conversion of ferrihydrite over a range of $\mathrm{Fe}$ (II) concentrations (Fig. 8). Although no magnetite was detected with the addition of 0.3 $\mathrm{mmol} / \mathrm{L}(0.5 \mathrm{mmol} \mathrm{Fe}[\mathrm{II}] / \mathrm{g}$ ferrihydrite $)$ ferrous iron to ferrihydrite, $11 \%$ of the ferrihydrite was converted to magnetite at $0.4 \mathrm{mmol} / \mathrm{L} \mathrm{Fe}$ (II) (1.0 mmol Fe[II]/g ferrihydrite) (within $9 \mathrm{~d}$ of reaction). At lower Fe(II) concentrations $(<0.3 \mathrm{mmol} / \mathrm{L})$, the loss of $\mathrm{Fe}$ (II) from solution is predominantly due to sorption on ferrihydrite (Fig. 8). The threshold value for magnetite precipitation thus corresponds to a change in the sequestration mechanism of $\mathrm{Fe}(\mathrm{II})$, shifting from adsorption to magnetite nucleation.

Alternatively, accumulation of $\mathrm{P}$ and/or Ca within the initial $2 \mathrm{~cm}$ of the column may hinder magnetite nucleation (Fig. 4). The strong adsorption of phosphate, and subsequent stabilization of the ferrihydrite surface, may inhibit internal recrystallization of ferrihydrite to magnetite (Couling and Mann, 1985; Fredrickson et al., 1998). Alternatively, precipitation of Ca- and/or P-bearing solids on the ferrihydrite surface may hinder further iron reduction. In fact, the effluent waters are saturated with respect to hydroxyapatite $\left(\mathrm{Ca}_{5}\left[\mathrm{PO}_{4}\right]_{3} \mathrm{OH}\right)$ and calcite $\left(\mathrm{CaCO}_{3}\right)$ (Table 2). Nonetheless, this appears to be a relatively minor factor due to the presence of lower $\mathrm{P}$ and $\mathrm{Ca}$ concentrations within the column $2 \mathrm{~cm}$ further downgradient, despite a continued absence of magnetite nucleation. We have similarly observed equivalent magnetite concentrations within a bicarbonate buffered media column study, where phosphate saturated the available iron oxide sites and underwent subsequent break-through (Benner et al., 2002). Thus, Fe(II) concentration appears to be the primary factor controlling magnetite formation.

\subsubsection{Role of flow and initial conditions}

The impact of flow rate was investigated by performing identical column experiments keeping all variables constant except decreasing the flow rate by one-sixth $\left(0.1 \mathrm{~m} \mathrm{~d}^{-1}\right)$. The visual discoloration and subsequent solid-phase distribution are different than the previous columns (Fig. 12; compare to Figs. 1 and 5). Longer residence times result in lactate initially $(<4$ d) being completely consumed within the bottom $10 \mathrm{~cm}$ of the column (inflow) and lactate does not reach the downgradient section of the column until $\sim 8 \mathrm{~d}$ (Fig. 12). Microbes, therefore, are initially starved of a carbon source and electron donor, thus inhibiting $\mathrm{Fe}(\mathrm{III})$ reduction within the latter two-thirds of the column. This results in a diffusive Fe(II) front moving downgradient, whereby low $\mathrm{Fe}(\mathrm{II})$ concentrations proceed a higher $\mathrm{Fe}$ (II) plume (Fig. 12). The extended period of low Fe(II) concentrations results in the accumulation of goethite downgradient. Over time, goethite continued to accumulate and constitutes nearly half of the iron solids within $50 \mathrm{~d}$. Even following the arrival of $\mathrm{Fe}$ (II) concentrations in excess of the previously observed $0.3 \mathrm{mmol} / \mathrm{L}$ threshold, magnetite is not detected in the downgradient two-thirds of the column. Accumulation of goethite therefore inhibits magnetite formation.

The contrasting solid-phase distribution obtained under slower flow conditions reveals the importance of initial conditions on $\mathrm{Fe}(\mathrm{II})$ profiles and subsequent mineralization pathways. Initially low $\mathrm{Fe}(\mathrm{II})$ results in goethite accumulation and magnetite inhibition upon higher Fe(II) concentrations. In con- 
trast, initially high $\mathrm{Fe}(\mathrm{II})$ results in simultaneous goethite and magnetite precipitation with continued magnetite accumulation at the expense of further goethite precipitation.

\subsubsection{Reaction kinetics and inhibition}

On the basis of solid-phase distributions noted under dynamic flow in the preceding sections, either the rate of goethite precipitation is faster than that of magnetite allowing for an initial accumulation of goethite or the precipitation rates are equivalent but a threshold amount of magnetite is required before inhibition ensues. Correspondingly, differences in precipitation rates are observed in abiotic kinetic studies using 2 $\mathrm{mmol} / \mathrm{L}$ ferrous sulfate and ferrihydrite (Fig. 9). More than half of the ferrihydrite is converted to goethite within the first $2 \mathrm{~h}$ of reaction, whereas appreciable magnetite accumulation is not observed until $>12 \mathrm{~h}$ of reaction. In contrast with the slower flow columns, the initial accumulation of goethite does not inhibit magnetite precipitation within the abiotic system. This further illustrates the importance of initial conditions in dictating the reaction pathways. Within the slower flow columns, low concentrations of $\mathrm{Fe}$ (II) initially move downgradient followed days later by a higher Fe(II) plume. In contrast, high Fe(II) concentrations are instantaneously added to the ferrihydrite in the abiotic experiments. The difference in inhibition processes suggests that when high concentrations of $\mathrm{Fe}(\mathrm{II})$ are introduced to ferrihydrite, goethite and magnetite precipitate simultaneously yet goethite has a faster growth rate. However, consistent with the faster flow biotic columns, magnetite continues to precipitate at the expense of goethite within the abiotic system (Fig. 9). Upon continued magnetite precipitation, Ostwald ripening (dissolution/reprecipitation) of ferrihydrite toward goethite is impeded, potentially due to magnetite's lower solubility and subsequent decline in Fe(III) activity. Similarly, formation of magnetite may induce goethite dissolution potentially explaining the decline in goethite concentrations following magnetite precipitation within the abiotic studies (Fig. 9).

\subsubsection{Nucleation and crystal growth}

Temporal variations in ferrous iron concentrations may support different precipitation mechanisms. The TEM images reveal two dominant precipitation mechanisms for magnetite, solid-state conversion of ferrihydrite and crystal growth (Fig. $7 \mathrm{~g}$ ). Nucleation of magnetite is initiated by sorption of $\mathrm{Fe}(\mathrm{II})$ on ferrihydrite followed by a solid-state conversion of the ferrihydrite to magnetite (Tronc et al., 1992). Correspondingly, nucleation is evident throughout ferrihydrite (arrows in Fig. 7g). However, larger $(\sim 50 \mathrm{~nm})$ magnetite crystals are observed growing away from the ferrihydrite surface, indicative of crystal growth rather than solid-state conversion. If higher $\mathrm{Fe}(\mathrm{II})$ concentrations $(>0.3 \mathrm{mmol} / \mathrm{L}$ or $0.5 \mathrm{mmol} \mathrm{Fe}[\mathrm{II}] / \mathrm{g}$ ferrihydrite) are required for magnetite nucleation, as suggested above, then continued precipitation within the column in the presence of declining $\mathrm{Fe}(\mathrm{II})$ concentrations supports crystal growth rather than nucleation as the dominant mechanism. The operating controls on nucleation versus crystal growth may therefore vary both spatially and temporally. Specifically, while ferrous iron and $\mathrm{pH}$ are the solution variables controlling mag- netite nucleation (reaction 2), ferric iron must also be considered for crystal growth (reaction 3).

$$
\text { nucleation: } 2 \mathrm{Fe}(\mathrm{OH})_{3}+\mathrm{Fe}^{2+}=\mathrm{Fe}_{3} \mathrm{O}_{4}+2 \mathrm{H}_{2} \mathrm{O}+2 \mathrm{H}^{+}
$$

$$
\text { growth: } \mathrm{Fe}^{2+}+2 \mathrm{Fe}^{3+}+4 \mathrm{H}_{2} \mathrm{O}=\mathrm{Fe}_{3} \mathrm{O}_{4}+8 \mathrm{H}^{+}
$$

Thus, ferrihydrite and/or goethite dissolution and subsequent $\mathrm{Fe}$ (III) activities may also contribute greatly to the precipitation of magnetite when $\mathrm{Fe}$ (II) concentrations decline and precipitation mechanisms shift from nucleation to crystal growth.

\subsection{Cessation of Microbial Metabolism}

During the 16-d reaction period, microbial numbers decrease from $\sim 10^{8}$ to $\sim 10^{4}$ to $10^{5} \mathrm{CFU} \mathrm{\textrm {g } ^ { - 1 }}$ and lactate oxidation declines (Fig. 3). The initial decrease in viable cells between 2 and $4 \mathrm{~d}$, however, does not coincide with a decrease in acetate nor Fe(II) generation. This suggests, therefore, that the decline in viable cells represents the microbial cell capacity of the ferrihydrite-coated sand, whereby excess organisms are subsequently eluted from the column. Conversely, the decrease in viable cells from 4 to $16 \mathrm{~d}$ coincides with a decline in acetate generation, reflecting a decay in microbial respiration. Of particular interest is that reduction declines appreciably, yet $>80 \%$ of the iron remains in the ferric state. Similarly, $\sim 50 \%$ of the original ferrihydrite remains within the column. We offer a number of potential explanations for the decline in microbial reduction: (1) passivation of the ferrihydrite surface by $\mathrm{Fe}(\mathrm{II})$ sorption, (2) passivation of the microbial cell by Fe(II) sorption and/or goethite encrustation, (3) sequestration of Fe(III) within the relatively stable, inverse spinel structure of magnetite, (4) declining surface area as a result of conversion to magnetite/ goethite, and/or (5) lack of phosphate. While magnetite reduction is feasible below $\mathrm{pH} \mathrm{7,} \mathrm{bioreduction} \mathrm{of} \mathrm{magnetite} \mathrm{at}$ circumneutral $\mathrm{pH}$ is most likely negligible (Kostka and Nealson, 1995; Dong et al., 2000). Yet, at the inlet of the column, magnetite nucleation is minimal $(<5 \%)$ and goethite has a patchy distribution on the ferrihydrite surface, negating these two factors as reduction inhibitors. Therefore, while magnetite nucleation and decline in available surface area may inhibit continued microbial reduction downgradient, within the first 5 $\mathrm{cm}$ of the column, other inhibition mechanisms are operative (either mechanism 1 or 2 above). Differentiating between microbial or substrate passivation is difficult due to the inability to separate the microbes from the solid-phase without disrupting the sorbate/precipitate-microbe relationships. Nevertheless, $\mathrm{Fe}$ (II) sorption to both the microbial cell (Urrutia et al., 1999; Roden and Urrutia, 2002) and mineral surface (Roden and Urrutia, 1999, 2002; Roden et al., 2000) has been previously demonstrated as a prevailing control on the decline or cessation of dissimilatory iron reduction. Additionally, the minor concentrations of available phosphate will, most certainly, further impede microbial growth.

\section{CONCEPTUAL MODEL AND CONCLUSIONS}

\subsection{Mineralization Pathways}

Based on the results of the biotic column and abiotic batch studies, we propose a conceptual model of Fe mineralization 


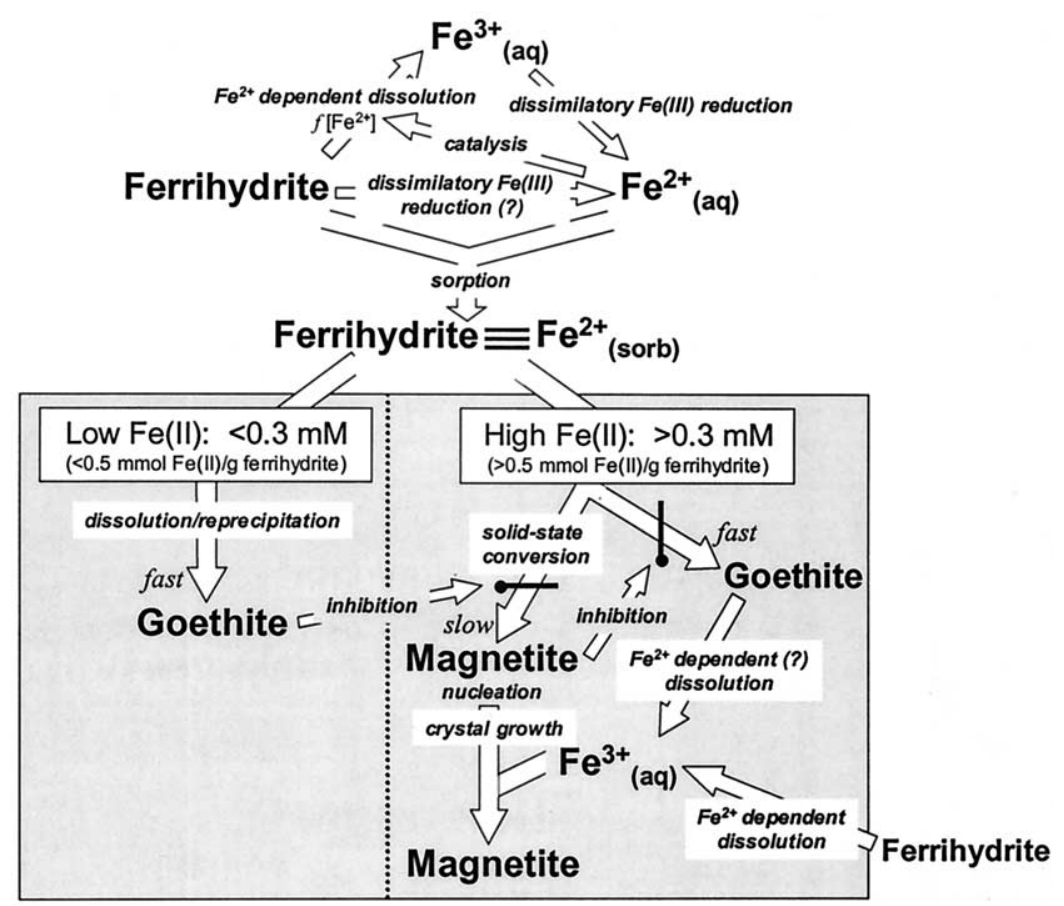

Fig. 13. Conceptual model of the secondary mineralization pathways following dissimilatory iron reduction of 2-line ferrihydrite by Shewanella putrefaciens.

pathways following dissimilatory iron reduction of 2-line ferrihydrite (Fig. 13). Ferrous iron is first generated through dissimilatory iron reduction of ferrihydrite. The rapid conversion of ferrihydrite to goethite is then catalyzed by bacterially generated ferrous iron, even at low concentration $(0.04 \mathrm{mmol} /$ L). Because goethite precipitation occurs via dissolution and reprecipitation, an initial flux of ferric iron to solution must ensue. The amount of Fe(II) sorbed on ferrihydrite, however, will dictate the successive mineralization pathways (of which there are two) and resulting mineral assemblage. If $\mathrm{Fe}(\mathrm{II})$ concentrations are initially high (above $0.3 \mathrm{mmol} / \mathrm{L} \mathrm{Fe}[\mathrm{II}]_{\mathrm{aq}}$, equivalent to $0.5 \mathrm{mmol} \mathrm{Fe}[\mathrm{II}] / \mathrm{g}$ ferrihydrite), both goethite and magnetite (simultaneously) precipitate. Goethite precipitation is more rapid than magnetite, resulting in an initial accumulation of goethite. Over time, however, magnetite continues to precipitate, eventually at the expense of goethite (limiting further precipitation and invoking dissolution of existing material). Furthermore, magnetite precipitation continues as a result of $\mathrm{Fe}$ (III)-dependent crystal growth even when ferrous Fe concentrations decline.

At low initial $\mathrm{Fe}(\mathrm{II})$ concentrations $(<0.3 \mathrm{mmol} / \mathrm{L})$, only goethite precipitation occurs. Furthermore, magnetite precipitation is not detected even if higher $\mathrm{Fe}(\mathrm{II})$ concentrations are later introduced. Accumulation of goethite, therefore, inhibits magnetite nucleation, potentially due to surface passivation of ferrihydrite since the solid-state conversion of goethite to magnetite is structurally prohibited. Accordingly, the initial ferrous Fe profiles, which will be controlled by microbial Fe(III) reduction rates and rates of advective flow, dictate the operating mineralization pathways and subsequent mineral assemblages.

\subsection{Implications}

Iron biomineralization of 2-line ferrihydrite occurs via a coupled biotic-abiotic process. Enzymatically produced ferrous iron reacts abiotically with ferrihydrite, producing goethite and magnetite. Owing to the precipitation mechanism of goethite (dissolution-reprecipitation), a flux of ferric iron to solution must occur. The solubilized ferric iron may therefore undergo reduction by $S$. putrefaciens, and provides a new concept for means by which bacteria may access Fe(III) from sparingly soluble iron oxides. This mechanism adds to those previously postulated, which include (1) production of soluble electron shuttles (e.g., quinones), (2) production of $\mathrm{Fe}(\mathrm{III})$-chelating compounds, and (3) direct contact of the bacterium with the surface allowing for electron flow through extracellular enzymes. Iron-reducing bacteria may differ in their strategy of $\mathrm{Fe}(\mathrm{III})$ acquisition from Fe oxides; Geobacter metallireducens requires direct contact with the surface (Nevin and Lovley, 2000), whereas some Shewanella and Geothrix species produce electron shuttles and/or Fe(III)-chelators (Newman and Kolter, 2000; Nevin and Lovley, 2002a, 2002b). All such organisms would seem to benefit from $\mathrm{Fe}(\mathrm{II})$ stimulated dissolution of ferrihydrite.

Primary biomineralization pathways are governed by a dynamic interplay between microbial metabolism, aqueous geochemistry, and kinetically regulated solid-phase precipitation. Secondary mineralization pathways, following reductive dissolution of ferrihydrite at a given $\mathrm{pH}$, are primarily governed by flow-regulated $\mathrm{Fe}$ (II) concentration, which ultimately drives mineral precipitation kinetics and selection of competing mineral pathways and molds the final mineral assemblage. As such, 
understanding the factors influencing biomineralization pathways lends insight into the mechanisms of mineral formation, provides a framework for further biogeochemical evolution, and assists in predicting contaminant behavior within natural systems.

Acknowledgments-We would like to thank Dr. Bruce Wielinga for helpful discussions and experimental conceptualization and Theresa Barber for laboratory assistance. This research was funded by the Natural and Accelerated Bioremediation Research (NABIR) program, Biologic and Environmental Research (BER), U.S. Department of Energy (grant DE-FG03-00ER63029). X-ray absorption spectroscopy was carried out at the Stanford Synchrotron Radiation Laboratory, a national user facility operated by Stanford University on behalf of the U.S. Department of Energy, Office of Basic Energy Sciences. The SSRL Structural Molecular Biology Program is supported by the Department of Energy, Office of Biologic and Environmental Research, and by the National Institutes of Health, National Center for Research Resources, Biomedical Technology Program. The authors are also grateful to two anonymous reviewers for their helpful comments and suggestions.

\section{Associate editor: P. A. Maurice}

\section{REFERENCES}

Allison J. D., Brown D. S., and Nova-Gradac K. J. (1990) MINTEQA2/ PRODEFA2, a Geochemical Assessment Model for Environmental Systems: Version 3.0 User's Manual. U.S. Environmental Protection Agency, Washington, DC.

Balch W. E., Fox G. E., Magrum L. J., Woese C. R., and Wolfe R. S. (1979) Methanogens: Re-evaluation of a unique biological group. Microbiol. Rev. 43, 260-296.

Banfield J. F., Welch S. A., Zhang H., Thomsen Ebert T., and Penn R. L. (2000) Aggregation-based crystal growth and microstructure development in natural iron oxyhydroxide biomineralization products. Science 289, 751-754.

Benner S. G., Hansel C. M., Wielinga B. W., Barber T. M., and Fendorf S. (2002) Reductive dissolution and biomineralization of iron hydroxide under dynamic flow conditions. Environ. Sci. Technol. 36, 1705-1711.

Bocquet S., Pollard R. J., and Cashion J. (1992) Dynamic magnetite phenomena in fine-particle goethite. Phys. Rev. B 46, 657-664.

Brooks S. C., Taylor D. L., and Jardine P. M. (1996) Reactive transport of EDTA-complexed cobalt in the presence of ferrihydrite. Geochim. Cosmochim. Acta 60, 1899-1908.

Cooper D. C., Picardal F., Rivera J., and Talbot C. (2000) Zinc immobilization and magnetite formation via ferric oxide reduction by $S h$ ewanella putrefaciens 200. Environ. Sci. Technol. 34, 100-106.

Cornell R. M. (1988) The influence of some divalent cations on the transformation of ferrihydrite into more crystalline products. Clay Miner. 23, 329-332.

Cornell R. M. and Schwertmann U. (1996) The Iron Oxides: Structure, Properties, Reactions, Occurrence and Uses. VCH Publishers, New York.

Couling S. B. and Mann S. (1985) The influence of inorganic phosphate on the crystallization of magnetite $\left(\mathrm{Fe}_{3} \mathrm{O}_{4}\right)$ from aqueous solution. J. Chem. Soc. Chem. Comm. pp. 1713-1715.

Dong H., Fredrickson J. K., Kennedy D. W., Zachara J. M., Kukkadapu R. K., and Onstott T. C. (2000) Mineral transformations associated with the microbial reduction of magnetite. Chem. Geol. 169, 299318.

dos Santos Afonso M. and Stumm W. (1992) Reductive dissolution of iron(III) (hydr)oxides by hydrogen sulfide. Langmuir 8, 1671-1675.

Fredrickson J. K., Zachara J. M., Kennedy D. W., Dong H., Onstott T. C., Hinman N. W., and Li S.-M. (1998) Biogenic iron mineralization accompanying the dissimilatory reduction of hydrous ferric oxide by a groundwater bacterium. Geochim. Cosmochim. Acta $\mathbf{6 2}$, $3239-3257$.

Fredrickson J. K., Zachara J. M., Kukkadapu R. K., Gorby Y. A., Smith S. C., and Brown C. F. (2001) Biotransformation of Ni-substituted hydrous ferric oxide by an $\mathrm{Fe}(\mathrm{III})$-reducing bacterium. Environ. Sci. Technol. 35, 703-712.

Genin J.-M. R., Bourrie G., Trolard F., Abdelmoula M., Jaffrezic A., Refait P., Maitre V., Humbert B., and Herbillon A. (1998) Thermodynamic equilibria in aqueous suspensions of synthetic and natural $\mathrm{Fe}(\mathrm{II})-\mathrm{Fe}(\mathrm{III})$ green rusts: Occurrences of the mineral in hydromorphic soils. Environ. Sci. Technol. 32, 1058-1068.

George G. N. (1993) EXAFSPAK. Stanford Synchrotron Radiation Laboratory, Menlo Park, CA.

Glasauer S., Langley S., and Beveridge T. (2001) Sorption of Fe (hydr)oxides to the surface of Shewanella putrefaciens: Cell-bound fine-grained minerals are not always formed de novo. Appl. Environ. Microbiol. 67, 5544-5550.

Glasauer S., Langley S., and Beveridge T. (2002) Intracellular iron minerals in a dissimilatory iron-reducing bacterium. Science $\mathbf{2 9 5}$, $117-119$.

Grossl P. R. and Inskeep W. P. (1992) Kinetics of octacalcium phosphate crystal-growth in the presence of organic acids. Geochim. Cosmochim. Acta 56, 1955-1961.

Hoch A. R., Reddy M. M., and Aiken G. R. (2000) Calcite crystal growth inhibition by humic substances with emphasis on hydrophobic acids from the Florida Everglades. Geochim. Cosmochim. Acta 64, 61-72.

Inskeep W. P. and Bloom P. R. (1986) Kinetics of calcite precipitation in the presence of water-soluble organic ligands. Soil. Sci. Soc. Am. J. 50, 1167-1172.

Jonot C., Gilbert H., and Tobias C. (1973) Caracterisation de kaolinites ferriferes pa spectrometrie Mossbauer. Bull. Soc. Franc. Miner. Cristall. 96, 281-291.

Kostka J. E. and Nealson K. H. (1995) Dissolution and reduction of magnetite by bacteria. Environ. Sci. Technol. 29, 2535-2540.

Lovley D. R. (1991) Dissimilatory Fe(III) and Mn(IV) reduction. Microbiol. Rev. 55, 259-287.

Lovley D. R. and Phillips E. J. P. (1986) Availability of ferric iron for microbial reduction in bottom sediments of the freshwater tidal Potomac River. Appl. Environ. Microbiol. 52, 751-757.

Lovley D. R. and Phillips E. J. P. (1988) Novel mode of microbial energy metabolism: Organic carbon oxidation coupled to dissimilatory reduction of iron or manganese. Appl. Environ. Microbiol. 54 $1472-1480$.

Lovley D. R., Phillips E. J. P., and Lonergan D. J. (1991) Enzymatic versus nonenzymatic mechanisms for $\mathrm{Fe}$ (III) reduction in aquatic sediments. Environ. Sci. Technol. 25, 1062-1067.

Lovley D. R., Stolz J. F., Nord G. L. Jr., and Phillips E. J. P. (1987) Anaerobic production of magnetite by a dissimilatory iron-reducing microorganism. Nature 330, 252-254.

Lytle F. W., Greegor R. B., Sandstone D. R., Marques E. C., Wong J., Spiro C. L., Huffman G. P., and Huggins F. E. (1984) Measurements of soft x-ray absorption spectra with a fluorescent ion chamber. Nucl. Instrum. Methods Phys. Res. Sect. A 226, 542-548.

McNab T. K., Fox R. A., and Boyle J. F. (1968) Some magnetic properties of magnetite $\left(\mathrm{Fe}_{3} \mathrm{O}_{4}\right)$ microcrystals. J. Appl. Phys. 39, 5703-5711.

Morse J. W. and Arakaki T. (1993) Adsorption and coprecipitation of divalent metals with mackinawite (FeS). Geochim. Cosmochim. Acta 57, 3635-3640.

Mortimer R. J. G. and Coleman M. L. (1997) Microbial influence on the isotopic composition of diagenic siderite. Geochim. Cosmochim. Acta 61, 1705-1711.

Nealson K. H. and Saffarini D. (1994) Iron and manganese in anaerobic respiration: Environmental signficance, physiology, and regulation. Ann. Rev. Microbiol. 48, 311-343.

Nevin K. P. and Lovley D. R. (2000) Lack of production of electronshuttling compounds or solubilization of $\mathrm{Fe}$ (III) during reduction of insoluble Fe(III) oxide by Geobacter metallireducens. Appl. Environ. Microbiol. 66, 2248-2251.

Nevin K. P. and Lovley D. R. (2002a) Mechanisms of Fe(III) oxide reduction in sedimentary environments. Geomicrobiol. J. 19, 141-159.

Nevin K. P. and Lovley D. R. (2002b) Mechanisms of accessing insoluble $\mathrm{Fe}(\mathrm{III})$ oxide during dissimilatory $\mathrm{Fe}(\mathrm{III})$ reduction by Geothrix fermentans. Appl. Environ. Microbiol. 68, 2294-2299.

Newman D. K. and Kolter R. (2002) A role for excreted quinones in extracellular electron transfer. Nature 405, 93-97. 
Phillips E. J. P., Lovley D. R., and Roden E. E. (1993) Composition of non-microbially reducible $\mathrm{Fe}(\mathrm{III})$ in aquatic sediments. Appl. Environ. Microbiol. 59, 8, 2727-2729.

Rancourt D. G. and Ping J. Y. (1991) Voigt-based methods for arbitrary-shape static hyperfine parameter distribution in Mossbauer spectroscopy. Nucl. Inst. Meth. Phys. Res. B 58, 85-97.

Roden E. E. and Lovley D. R. (1993) Dissimilatory Fe(III) reduction by the marine microorganism Desulfuromonas acetoxidans. Appl. Environ. Microbiol. 59, 734-742.

Roden E. E. and Zachara J. M. (1996) Microbial reduction of crystalline iron(III) oxides: Influence of oxide surface area and potential for cell growth. Environ. Sci. Technol. 30, 1618-1628.

Roden E. E. and Urrutia M. M. (1999) Ferrous iron removal promotes microbial reduction of crystalline iron(III) oxides. Environ. Sci. Technol. 33, 1847-1853.

Roden E. E. and Urrutia M. M. (2002) Influence of biogenic Fe(II) on bacterial crystalline $\mathrm{Fe}(\mathrm{III})$ oxide reduction. Geomicrobiol. J. 19, 209-251.

Roden E. E., Urrutia M. M., and Mann C. J. (2000) Bacterial reductive dissolution of crystalline $\mathrm{Fe}$ (III) oxide in continuous-flow column reactors. Appl. Environ. Microbiol. 66, 1062-1065.
Schwertmann U. and Fechter H. (1994) The formation of green rust and its transformation to lepidocrocite. Clay Miner. 29, 87-92.

Schwertmann U. and Cornell R. M. (2000) Iron Oxides in the Laboratory: Preparation and Characterization. Wiley-VCH, New York.

Stookey L. L. (1970) Ferrozine-A new spectrophotometric reagent for iron. Anal. Chem. 42, 779-781.

Tronc E., Belleville P., Jolivet J. P., and Livage J. (1992) Transformation of ferric hydroxide into spinel by Fe(II) adsorption. Langmuir $\mathbf{8}$, 313-319.

Urrutia M. M., Roden E. E., and Zachara J. M. (1999) Influence of aqueous and solid-phase $\mathrm{Fe}(\mathrm{II})$ complexants on microbial reduction of crystalline iron(III) oxides. Environ. Sci. Technol. 33, 4022-4028.

Zachara J. M., Fredrickson J. K., Smith S. C., and Gassman P. L. (2001) Solubilization of Fe(III) oxide-bound trace metals by a dissimilatory $\mathrm{Fe}(\mathrm{III})$ reducing bacterium. Geochim. Cosmochim. Acta 65, 75-93.

Zachara J. M., Kukkadapu R. K., Fredrickson J. K., Gorby Y. A., and Smith S. C. (2002) Biomineralization of poorly crystalline Fe(III) oxides by dissimilatory metal reducing bacteria (DMRB). Geomicrobiol. J. 19, 179-207. 